\title{
Comparative in vitro study regarding the biocompatibility of titanium-base composites infiltrated with hydroxyapatite or silicatitanate
}

Ioana-Carmen Brie ${ }^{1,2}$, Olga Soritau ${ }^{1 *}$, Noemi Dirzu ${ }^{3}$, Cristian Berce ${ }^{2}$, Adriana Vulpoi $^{4}$, Catalin Popa ${ }^{3}$, Milica Todea ${ }^{4}$, Simion Simon ${ }^{4}$, Maria Perde-Schrepler ${ }^{1}$, Piroska Virag ${ }^{1}$, Otilia Barbos ${ }^{1}$, Gabriela Chereches ${ }^{1}$, Petru Berce ${ }^{3}$ and Valentin Cernea ${ }^{1,2}$

\begin{abstract}
Background: The development of novel biomaterials able to control cell activities and direct their fate is warranted for engineering functional bone tissues. Adding bioactive materials can improve new bone formation and better osseointegration. Three types of titanium (Ti) implants were tested for in vitro biocompatibility in this comparative study: Ti6Al7 Nb implants with 25\% total porosity used as controls, implants infiltrated using a sol-gel method with hydroxyapatite $(\mathrm{Ti} \mathrm{HA})$ and silicatitanate $\left(\mathrm{Ti}_{\mathrm{SiO}}\right)$. The behavior of human osteoblasts was observed in terms of adhesion, cell growth and differentiation.

Results: The two coating methods have provided different morphological and chemical properties (SEM and EDX analysis). Cell attachment in the first hour was slower on the $\mathrm{Ti} \mathrm{HA}$ scaffolds when compared to $\mathrm{Ti}_{\mathrm{SiO}}$ and porous uncoated Ti implants. The Alamar blue test and the assessment of total protein content uncovered a peak of

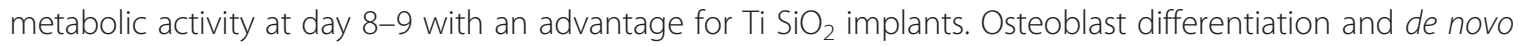
mineralization, evaluated by osteopontin (OP) expression (ELISA and immnocytochemistry), alkaline phosphatase (ALP) activity, calcium deposition (alizarin red), collagen synthesis (SIRCOL test and immnocytochemical staining) and osteocalcin (OC) expression, highlighted the higher osteoconductive ability of Ti HA implants. Higher soluble collagen levels were found for cells cultured in simple osteogenic differentiation medium on control $\mathrm{Ti}$ and $\mathrm{Ti} \mathrm{SiO}_{2}$ implants. Osteocalcin (OC), a marker of terminal osteoblastic differentiation, was most strongly expressed in osteoblasts cultivated on $\mathrm{Ti}_{\mathrm{SiO}}$ implants.
\end{abstract}

Conclusions: The behavior of osteoblasts depends on the type of implant and culture conditions. $\mathrm{Ti} \mathrm{SiO}_{2} \mathrm{scaffolds}$ sustain osteoblast adhesion and promote differentiation with increased collagen and non-collagenic proteins (OP and OC) production. Ti HA implants have a lower ability to induce cell adhesion and proliferation but an increased capacity to induce early mineralization. Addition of growth factors BMP-2 and TGF $\beta 1$ in differentiation medium did not improve the mineralization process. Both types of infiltrates have their advantages and limitations, which can be exploited depending on local conditions of bone lesions that have to be repaired. These limitations can also be offset through methods of functionalization with biomolecules involved in osteogenesis.

Keywords: Implants, Porous titanium, Hydroxyapatite, Silicatitanate, Osteoblasts, Cell adhesion, Differentiation, Mineralization

\footnotetext{
* Correspondence: olgasoritau@yahoo.com

'The Institute of Oncology "Prof. Dr. I. Chiricuta" Cluj-Napoca, Cluj-Napoca, Romania

Full list of author information is available at the end of the article
} 


\section{Background}

Current procedures to repair bone defects include the use of grafts or implants, yet these approaches face important limitations. Bone tissue engineering has seen tremendous development over the years, as much collaborative effort of scientists, surgeons and engineers has been spent to create bone implants and/or grafts which enhance bone repair and regeneration.

The very first requirements of any implantable material are related to the toxicological aspects: bone implants/ grafts need to be sterile, free of pyrogens, made of pure molecules and biocompatible with tissues and body fluids [1]. The classic paradigm of bone tissue engineering highlights several key players: a biocompatible scaffold, osteogenic cells, morphogenic signals and vascularization [2] The biocompatibility requirement stresses the selection of bone graft/implant composition so that it could be accepted and integrated by the host tissue.

The biomaterial's surface topography, chemistry and mechanical characteristics influence cell functions by triggering specific molecular events at the cell-material interface: cell adhesion, spreading, migration, proliferation and differentiation [3-5].

One of the best biomaterials is titanium (Ti), which stands out with its remarkable properties: good biocompatibility, low density, good mechanical properties and better resistance to corrosion. But, even if well tolerated by the human body, $\mathrm{Ti}$ and its alloys are bioinert and cannot promote tissue bonding to the implant. Many clinical problems regarding $\mathrm{Ti}$ implants are reported in the literature, such as weakness of osseointegration in the case of long-term implants and tissue inflammatory response at the implantation sites due by release of titanium particles in surrounding tissues [6-8]. Other problems are caused by loss of ability of bone remodeling caused by implant stiffness and biomechanical mismatch $[9,10]$.

In order to solve those medical problems, surface coating of titanium implants with specifically engineered bioactive materials is beneficial in that it stimulates new bone formation and promotes better osseointegration [11]. Bioactivity is a surface property of the implant which allows the chemical integration of synthetic materials with the host's tissue, inducing the formation of extracellular matrix with biomineralization of calcium phosphate nanocrystallites at the bioactive substrate/tissue interface [12]. New methods that combine the bioactivity of HA or bioactive glass and the mechanical properties of $\mathrm{Ti}$ or $\mathrm{Ti}$ alloys have been intensively investigated in the past decades, and implants coated with plasma-sprayed HA have already entered the clinical practice $[13,14]$. The chemical and crystallographic structure of HA is similar to bone minerals and consequently is biocompatible and osseoconductive, yet its poor mechanical properties are obstacles in the designing of bone implants [15]. The release of toxic elements by the metal implants coated with bioactive ceramics and the differences in thermal expansion between the ceramic substrate and metal are other disadvantages [16]. In order to avoid brittleness and to increase the bond strength between HA and Ti alloys, different methods of HA coatings were tested: plasma spray, pulse laser-deposition $[17,18]$, combined laser and induction plasma spraying [19], mechanical alloying [20], sol-gel process [21], HA growth in simulated body fluid [22] or electrophoretic deposition [23]. A method for obtaining biocomposites from Ti powder, HA and bioactive glass, with the aim of improving the mechanical and biological properties of HA, was described by Ning et al. [15].

Bioactive glasses coatings of metal implants are also used to improve bone-binding ability by promoting protein adsorbtion and forming biologically active apatite layers upon implantation [24,14]. Saino et al. reported enhancement of human osteoblasts SAOS-2 calcium deposition after culturing on Ti-6Al-4 $\mathrm{V}$ scaffolds coated with bioglass [25].

In the present study, the in vitro biocompatibility was determined using Ti6Al7Nb implants with 25\% total porosity, processed with Selective Laser Melting (SLM) technology, infiltrated with hydroxyapatite and silicatitanate using a sol-gel method, in an attempt to improve the bioactivity of the material. Human osteoblast behavior was observed in terms of adhesion, cell growth and differentiation. The ability of Ti implants to induce osseoinduction was studied by scanning electron microscopy (SEM) and fluorescence microscopy with cytochemical stains for cell adhesion. Osteoblast proliferation was assessed through viability tests and assessment of total protein synthesis, whilst the expression of molecules involved in osteoblast differentiation (osteopontin, osteocalcin, alkaline phosphase and collagen) was investigated through immunocytochemical staining and quantitative assays. The mineralization process, as an important component of implant integration in bone tissue, was evaluated through measurements of the calcium deposits on the Ti implants. The experiments were conducted under different environmental conditions: standard medium with fetal calf serum (FCS), serum-free medium, specific osteogenic differentiation mediums: simple and complex (supplemented with growth factors).

\section{Materials and methods Implants}

The atomized Ti6Al7Nb powder (MCP HEK GmbH), medical grade, as the control material, was processed with a Selective Laser Melting machine Realizer II SLM 250 with a Nd: YAG (fibre laser). Test specimens of $10 \mathrm{~mm} \times$ $5 \mathrm{~mm} \times 3 \mathrm{~mm}$ were manufactured with a laser power of $50 \mathrm{~W}$, the laser spot size $150 \mu \mathrm{m}$, layer thickness $50 \mu \mathrm{m}$, 
hatch spacing $100 \mu \mathrm{m}$ and scan speed $400 \mathrm{~mm} / \mathrm{s}$. The successive layers were deposited in the " $\mathrm{z}$ " direction. The samples were built on a titanium plate whose temperature was kept at approximately $473^{\circ} \mathrm{K}\left(200^{\circ} \mathrm{C}\right)$, in argon atmosphere. The manufactured specimens were cleaned ultrasonically in distilled water for $10 \mathrm{~min}$. and dried at $353^{\circ} \mathrm{K}$ $\left(80^{\circ} \mathrm{C}\right)$ for $30 \mathrm{~min}[26]$.

In order to improve the bioactivity of the resulted titanium base specimens, their pores were infiltrated with calcium phosphate precipitates and silicatitanate gel, respectively. Two types of calcium phosphate precipitates A $(\mathrm{pH}=4.5)$ and $\mathrm{B}(\mathrm{pH}=10)$ were synthetized through wet chemical precipitation from calcium nitrate tetrahydrate$\mathrm{Ca}\left(\mathrm{NO}_{3}\right)_{2} \cdot 4 \mathrm{H} 2 \mathrm{O}$ and diammonium hydrogen phosphate$\left(\mathrm{NH}_{4}\right) 2 \mathrm{HPO}_{4}$ (Sigma Aldrich). The silicatitanate gel was obtained by the sol-gel method from titanium isopropoxide (TIP) with the formula $\mathrm{Ti}\left\{\mathrm{OCH}\left(\mathrm{CH}_{3}\right)_{2}\right\}_{4}$ and tetraethylorthosilicate (TEOS) with the formula $\mathrm{Si}\left(\mathrm{OC}_{2} \mathrm{H}_{5}\right)_{4}$. The preparation of $\mathrm{TiO}_{2} / \mathrm{SiO}_{2}$ gel included 2 steps. The first step involved the hydrolysis of $\operatorname{Ti}\left\{\mathrm{OCH}\left(\mathrm{CH}_{3}\right)_{2}\right\}_{4}$ to form the uniform sol. TIP was diluted with ethanol and a small amount of nitric acid $\mathrm{HNO}_{3}$ to form a transparent colloid. Then, distilled water with a small amount of nitric acid and the rest of ethanol were mixed together and dropped into the above colloid solution. The molar ratio of $\mathrm{Ti}$ $\left\{\mathrm{OCH}\left(\mathrm{CH}_{3}\right)_{2}\right\}_{4}: \mathrm{C} 2 \mathrm{H} 5 \mathrm{OH}: \mathrm{H} 2 \mathrm{O}: \mathrm{HCl}$ was 1:15:10:0.89. The colloid was then left to homogenize at room temperature for one hour. In the second step, TEOS was hydrolysed with a molar ratio of $\mathrm{Si}\left(\mathrm{OC}_{2} \mathrm{H}_{5}\right)_{4}: \mathrm{C} 2 \mathrm{H} 5 \mathrm{OH}: \mathrm{H} 2 \mathrm{O}: \mathrm{HCl}=$ 1:7.6:25:0.28. The $\mathrm{TiO}_{2}$ solution was then added dropwise to the above $\mathrm{SiO}_{2}$ sol to form the transparent $\mathrm{TiO}_{2} / \mathrm{SiO}_{2}$ sol mixture. The transparent mixture was left to homogenize at room temperature for $30 \mathrm{~min}$ before carrying out the infiltration into the pores of the titanium base specimens.

Concerning the infiltration of porous titanium implants, the obtained disks were immersed in the hydroxyapatite (HA) solution and silicatitanate gel, kept in vacuum (100 mbar) for $15 \mathrm{~min}$. Subsequently, the samples were dried at $60^{\circ} \mathrm{C}$, then at $110^{\circ} \mathrm{C}$ in an oven. All the specimens were sintered for $1 \mathrm{~h}$ in air atmosphere, using a furnace, at $600^{\circ} \mathrm{C}$ for samples with HA and $400^{\circ} \mathrm{C}$ for those infiltrated with silicatitanate gel [20]. The infiltrated samples were sterilized by exposing them to dry heat, at $180^{\circ} \mathrm{C}$ for 2 hours.

\section{Cell culture}

Human osteoblasts were isolated from patella bone pieces harvested during arthroplasty as described by Tomuleasa et al. [27]. Briefly, the bone fragments were first mechanically processed and then digested for 30 min with an enzymatic cocktail: $0.1 \%$ colagenase IV (Gibco $)+0.25 \%$ trypsin EDTA-4 (Sigma). The resulted bone explants were cultured in Dulbecco's modified Eagle's medium (DMEM)/F-12HAM (Sigma) containing 20\% fetal calf serum (FCS), 2 mM L-Glutamine, 1\% antibiotics, 1\% non-essential aminoacids (NEA) (all reagents from Sigma), in $25-\mathrm{cm}^{2}$ culture flasks (Nunc) in a humidified $7 \% \mathrm{CO} 2$ atmosphere. The first cells appeared near the explants after 14 days and the culture reached confluence after 6-8 weeks, when the explants were removed and cells were trypsinized and replated. The isolated cells were characterized at the second passage by immunocytochemical staining, showing positivity for osteoblastic lineage markers such as osteonectin (ON) and osteopontin (OP). The obtained cells showed a spindle-like shape in the first passages and a polygonal shape with multiple dendritic extensions in more advanced passages. The medium was changed twice each week and the cells were used after four to six passages.

In the differentiation experiments we used serum-free simple osteogenic medium (OS) consisting on DMEM/ F-12HAM without phenol red, $2 \mathrm{mM}$ L-Glutamine, 1\% antibiotics, 1\% NEA, $10 \mathrm{nM}$ dexamethasone, $50 \mu \mathrm{g} / \mathrm{ml}$ ascorbic acid and $10 \mathrm{mM} \beta$-glycero-phosphate or complex osteogenic medium (OC) consisting of the above mentioned simple osteogenic medium but supplemented with growth factors: $3 \mathrm{ng} / \mathrm{ml}$ transforming growth factor $\beta 1$ (TGF $\beta 1$ ) and $4 \mathrm{ng} / \mathrm{ml}$ bone morphogenetic protein 2 (BMP2). All the reagents were purchased from Sigma Aldrich. In some experiments cells were grown in the absence of fetal serum (FCS) in DMEM/F12 HAM medium without phenol red (serum-free medium, SF) after day 18, considering that the cell environment is an important component of variability in experiments and that the proteins present in fetal serum (FCS) may interfere with certain tests (e.g. determination of collagen or other proteins).

\section{Scanning electron microscopy (SEM)}

The scaffolds seeded with osteoblasts were fixed with $4 \%$ paraformaldehyde in phosphate buffered saline (PBS) after 1 hour and 28 days of cultivation on Ti implants. Implants were washed three times with PBS and immersed in PBS before analysis. Specimens were characterized with a Quanta 3D FEG Scanning Electron Microscope equipped with an energy-dispersive X-ray microanalyzer (EDX). Control implants without cells were also used for SEM and EDX analysis.

\section{Cell adhesion and proliferation}

Cell adhesion at 2 hours and cell proliferation were assessed with the Alamar blue test, which is used mainly to measure cell viability. Resazurine, a non-fluorescent dye is converted to resorufin (red fluorescence) in metabolically active cells, through a reduction mechanism. Fluorescence intensity depends on the number of viable cells. $8 \times 10^{5}$ cells/well were suspended in $1.5 \mathrm{ml}$ DMEM/ F12HAM complete medium and seeded on the implants 
placed in 12-well plates. Each assay was performed in triplicate. After 2 hours of cultivation, $150 \mu \mathrm{l}$ of Alamar blue (Invitrogen) were added to each well. The plates were incubated for 1 hour at $37^{\circ} \mathrm{C}$, in the dark. The medium was subsequently transferred to another 12-well plate and fluorescence intensity was measured using a BioTek Synergy 2 plate reader (excitation $540 \mathrm{~nm}$, emission $620 \mathrm{~nm}$ ). The cells were quantified at different time intervals: 2 hours, 24 hours, 9 days and 18 days.

Cell adhesion was also assessed through fluorescence microscopy with cytochemical stains: DAPI (4,6-diamidino2-phenylindole) for nuclei and TRITC (tetramethylrhodamine isothiocyanate) phalloidin (Sigma) for actin filaments. After 1 hour cultivation in complete medium on the $\mathrm{Ti}$ implants, cells were fixed with $4 \%$ paraformaldehyde solution and permeabilized with $0.1 \%$ Triton X-100 in PBS for $20 \mathrm{~min}$ at room temperature. TRITC phalloidine (1:20 in PBS) was used for the staining of filamentous actin. The samples were counterstained with an antifade medium containing DAPI (UltraCruz ${ }^{\mathrm{TM}}$ Mounting medium-Santa Cruz Biotechnologies) in order to highlight the nuclei. Slides were examined in reversed phase fluorescence with a Zeiss Axiovert D1 microscope, using filters at 340/ $360 \mathrm{~nm}$ for DAPI and $546 \mathrm{~nm}$ for TRITC. Cultures of osteoblasts on plastic dishes were used as negative controls. Manufactured discs of synthetic resins composed by 70\% wt Bis-GMA(2,2-bis[4-(2-hydroxy-3-methacryloxypropoxy)phenyl]-propane), 30\% wt TEGDMA (triethylene glycol dimethylacrylate), 1\%DHEPT(DihydroxyethylP-Toluidine), 0.035\%BHT (Butyl hydroxytoluene), 1.08\% BPO (Benzoyl peroxide) and 25.93\% $\beta$ TCP (Tricalcium phosphate) were used as positive control in adhesion studies.

Protein synthesis, as an indicator of cell proliferation, was evaluated by determining the total protein content in culture medium and cell lysates, using the microplate BioRad Protein assay - a colorimetric assay based on the Bradford dye-binding method. The test consists in obtaining a calibration curve of standard proteins (bovine serum albumine, BSA), which will serve for extrapolation of the values obtained from samples in spectroscopy absorbance. The osteoblasts were cultured on titanium implants, in 24-well plates, either in complete medium (with FCS) or in serum-free medium. Ten microliters of medium were collected from the cultures at different time points. Cell lysis was performed with CelLyticTM MTMammalian Tissue Lysis/Extraction ReagentCell (Sigma). Ten microliters of samples as well as decreasing known concentrations of standard BSA were added in each well of a 96well microplate. After adding $200 \mu$ l Dye Reagent (diluted 1:4 with deionizated water), the microplate was incubated $15 \mathrm{~min}$ at room temperature, and absorbance was measured with a BioTek Synergy 2 microplate reader at $595 \mathrm{~nm}$.

\section{Cell differentiation and secretion of the extracellular matrix}

Osteopontin (OP) was evaluated in cell culture medium (complete medium and serum-free medium) and cell lysates, using a R\&D Quantikine ELISA kit according to the manufacturer's instructions. Briefly, complete medium was harvested at days 8, 14, 21 and 28 and serum-free medium at day 21 and 28. Cell lysates were harvested after 8,14 and 24 days of cultivation. In each well of a microplate (coated with mouse monoclonal antibody against OP), $50 \mu \mathrm{l}$ of standards and undiluted samples were added. After 2 hours of incubation at room temperature and washing, $200 \mu \mathrm{l}$ of OP conjugate were added, followed by 2 hours incubation and further washing. After $30 \mathrm{~min}$ incubation with the substrate solution, the stop solution was added and optical density was determined with a microplate Biotek Synergy2 reader set to $450 \mathrm{~nm}$.

Alkaline phosphatase (ALP) activity was assessed in cell medium and cell lysates, using a fluorimetric Alkaline Phosphatase detection kit (Sigma Aldrich). The culture conditions were: medium with FCS, serum-free medium, simple medium and complex differentiation medium. Samples were harvested at different intervals, from 8 to 35 days. $20 \mu \mathrm{l}$ from each sample, negative control (DMEM/F12 HAM medium without phenol red) and positive control were added in each well of a black 96-well microplate. The samples were incubated for $20 \mathrm{~min}$ at $65^{\circ}$ $\mathrm{C}$, cooled for $2 \mathrm{~min}$ on ice to stabilize at room temperature and $180 \mu \mathrm{l}$ mixture of Dilution Buffer and Fluorescent Assay Buffer at 1:8 ratio were added. Activity of alkaline phosphatase was measured at different points in time, with a Biotek Synergy 2 fluorometer at $360 \mathrm{~nm}$ excitation and $440 \mathrm{~nm}$ emission.

Calcium deposits that are formed after the mineralization process can be highlighted with Alizarin red - an anthraquinone derivate and calcium chelator. Osteoblasts seeded and cultivated on titanium implants, either in medium with FCS or serum-free medium, were fixed with $4 \%$ paraformaldehyde after 14, 21 and 28 days. After washing with deionized water, $\mathrm{Ti}$ implants were incubated for $10 \mathrm{~min}$ at room temperature with $2 \%$ Alizarin red solution ( $\mathrm{pH} 4.1$ ). After intensive washing of implants a destaining method was used, with $10 \%(\mathrm{w} / \mathrm{v})$ cetylpyridinium chloride (CPC) (Sigma) in $10 \mathrm{mM}$ sodium phosphate ( $\mathrm{pH} 7.0)$. After $15 \mathrm{~min}$ at room temperature, aliquots from the extracted stain were transferred to a 96-well plate and diluted 10 fold with CPC solution. The violetcolored supernatant was read with a microplate reader at $562 \mathrm{~nm}$.

\section{Collagen detection}

The most abundant protein of the extracellular matrix, collagen, was determined with the SIRCOL collagen assay, a colorimetric method based on staining of collagen with 
Sirius red. Samples were cultured in serum-free medium, simple medium and complex osteogenic differentiation medium. Medium was harvested at day 21 and 28 for serum-free medium and at day 35 for differentiation medium. $100 \mu \mathrm{l}$ of collagen standards, samples, negative controls (medium) and $1 \mathrm{ml}$ Sircol Dye Reagent were added to low protein binding microcentrifuge tubes and incubated $30 \mathrm{~min}$ on an orbital shaker. After centrifuging and draining the tubes, $750 \mu \mathrm{l}$ of ice-cold Acid-Salt Wash Reagent were added followed by another centrifugation for removal of the unbound dye. $250 \mu \mathrm{l}$ of Alkali Reagent were used to release the Sircol dye from the collagen-dye complex. Samples were transferred on a 96-well plate and absorbance was measured with a microplate reader at $555 \mathrm{~nm}$.

\section{Immunocytochemical staining}

Osteoblasts cultivated on titanium implants for 3, 14, 21 and 28 days in complete medium with FCS, were fixed with $4 \%$ paraformaldehyde solution and permeabilized with $0.1 \%$ Triton $\mathrm{X}-100$ for $20 \mathrm{~min}$ at room temperature. The samples were kept for 20 minutes at room temperature with $10 \%$ BSA to avoid non-specific antibody binding. Osteopontin, osteocalcine, and collagen 1A1 (all mouse anti-human primary antibodies from Santa Cruz Biotechnologies) were diluted at a ratio of 1:50 in 1\% BSA and incubated overnight at $4^{\circ} \mathrm{C}$ with the samples. Secondary goat anti-mouse antibodies IgG1 marked with FITC (fluorescein isothiocyanate) and Texas Red (Santa Cruz Biotechnologies) were added and incubated for 45-60 minutes at $37^{\circ} \mathrm{C}$. Samples were counterstained with an antifade medium containing DAPI in order to highlight the nuclei and were subsequently examined with a reversed phase epifluorescence Zeiss Axiovert D1 microscope at $488 \mathrm{~nm}$ for FITC, $546 \mathrm{~nm}$ for Texas red and 340/360 nm for DAPI.

\section{Statistical analysis}

Statistical analysis was performed with the GraphPad Prism 5 software, using the Bonferroni Multiple Comparison test. Statistical significance was set at $\mathrm{p}<0.05$.

\section{Results}

The success of bone grafting with Ti implants depends on the properties of the implant (mechanical features, surface structure, chemical and physical features, porosity) and on the host's characteristics (bone bed, associated diseases, etc.) [28]. The biochemical and biophysical signals induced at the cell-material interface, which relay complex information resulting from molecular, topographic and mechanical properties of the substrate, trigger a cross-talk between the material and the cells with consequences on cellfunctions such as: early attachment (in the first seconds), cell adhesion and spreading, proliferation and differentiation [21]. The ability of the biomaterial to promote cell adhesion and proliferation is a critical factor for osseointegration. Adhesion allows the host's osteoblastics to attach to the substrate and activates a complex machinery of reorganization of intra and extracellular molecules. It promotes a specific cellular response consisting of the induction of a differentiation processes towards more specialized cell types, migration, proliferation and gene expression of specific proteins [29]. To enhance bone ingrowth, solutions to enhance surface modification are currently being studied. One of the most promising is bioactive coating which seems to accelerate new bone formation at the bone-implant interface [30].

In the present study we used an original method to coat the porous titanium implants, through infiltration with calcium phosphate precipitates and silicatitanate gel, in vacuum conditions followed by sintering at $600^{\circ} \mathrm{C}$ (for samples with $\mathrm{HA}$ ) and at $400^{\circ} \mathrm{C}$ (for silicatitanate samples). The total porosity of $\mathrm{Ti}$ control implants before infiltration was evaluated by the Archimedes method (ISO 2738-99) and reached values of nearly 25\%. After infiltration of implants total porosity decreased to $22 \%$ for titanium infiltrated with hydroxiapatite and to $23 \%$ for titanium infiltrated with silicatitanate. The microstructure was analyzed with a metallographic microscope that revealed mainly irregular interconnected pores, with a minimum diameter $d_{\min }=70-100 \mu \mathrm{m}$ and a maximum diameter $d_{\max }=200-400 \mu \mathrm{m}$ [26]. Three different porous titanium implants were obtained and studied: porous titanium without infiltration ( $\mathrm{Ti} \mathrm{Ctrl}$ ), titanium infiltrated with hydroxiapatite ( $\mathrm{Ti} \mathrm{HA})$ and titanium infiltrated with silicatitanate $\left.(\mathrm{Ti} \mathrm{SiO})_{2}\right)$.

\section{Structural analysis}

The surfaces of the resulted implants were characterized using scanning electon microscopy (SEM) and elemental analysis by energy dispersive X-ray spectroscopy (EDX).

The SEM analysis revealed differences in the surface structure for the three implants studied (Figure 1). Infiltration with $\mathrm{HA}$ yielded a rough surface consisting of HA crystals covering almost entirely the titanium surface (Figure 1B). In case of the silicatitanate-infiltrated titanium $\left(\mathrm{Ti} \mathrm{SiO}_{2}\right)$, the pores were covered with silicatitanate gel and the film coating was transparent and almost continuous (Figure 1C).

The EDX analysis showed a pronounced decrease in titanium elemental content on the surface of HA infiltrated samples (30.25\%), and a much lower decrease in Ti SiO2 implants (43.65\%). The Ti implants infiltrated with HA had a Calcium (Ca) content of $17.04 \%$ and a Phosphorus (P) content of $7.37 \%$, with a $\mathrm{Ca} / \mathrm{P}$ ratio of 2.31 (Table 1).

Most studies in the literature reported $\mathrm{Ca} / \mathrm{P}$ ratios ranging between 0.5 and 1.9 [31]. Kitsugi et al. [32] used 


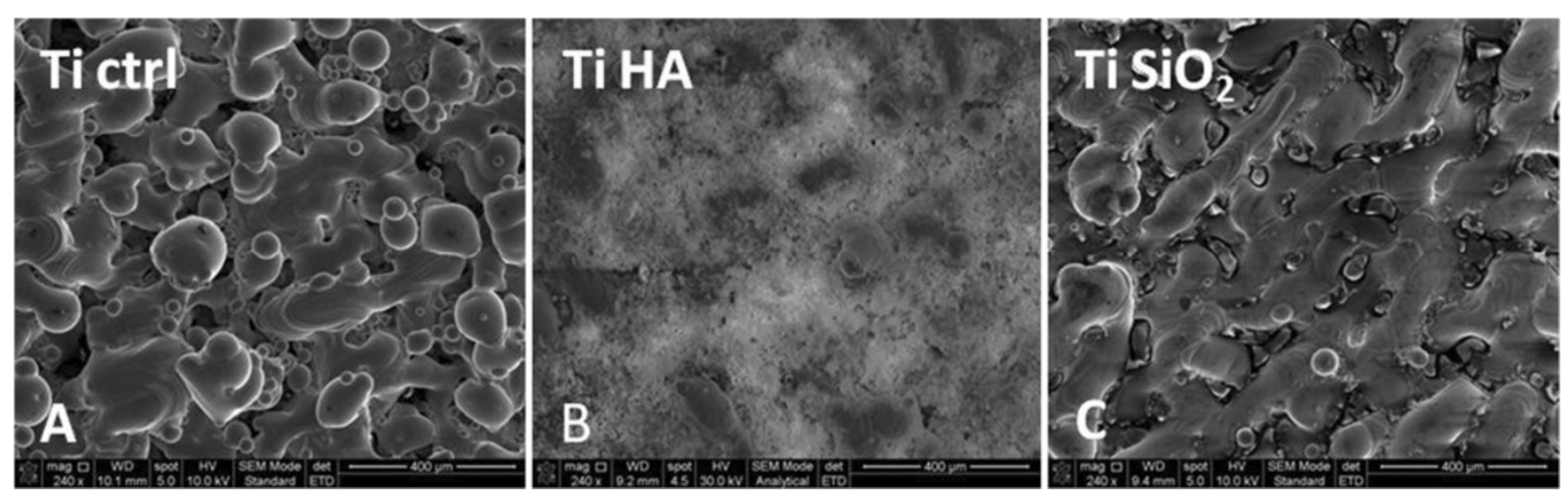

Figure 1 SEM images of the surfaces of the studied substrate. Legend A. Non-infiltrated titanium, Ti Ctrl; $\mathbf{B}$. Titanium infiltrated with hydroxyapatite, $\mathrm{Ti} \mathrm{HA}$; C. Titanium infiltrated with silicatitanate, $\mathrm{Ti}_{\mathrm{SiO}}$ (magnification 240X).

four kinds of calcium phosphate ceramics with $\mathrm{Ca} / \mathrm{P}$ ratios of 1.0, 1.5, 1.66 and 2. Transmission electron microscopy analysis showed that the bone-bonding behavior of calcium phosphate ceramics did not vary with the calcium/ phosphate molar ratio [32]. Silica content was $6.99 \%$.

\section{Osseoinduction: cell adhesion and proliferation}

The adherence of cells to the materials was evaluated through SEM imaging and cytochemical staining of nuclei at 1 hour after seeding the cells on titanium implants. Cell proliferation on substrates was assessed by a viability assay (Alamar blue test) and by quantification of the total protein contents in the cell culture medium or cellular lysates.

SEM images were captured one hour after seeding the implants with osteoblasts (Figure 2). We noticed changes of cell shape, with development of dendritic extensions and their attachment at several points, for the Ti Ctrl (Figure 2A) and $\mathrm{Ti} \mathrm{SiO} 2$ implants (Figure 2C). Cells grown on Ti HA implants maintained a rounded shape (Figure 2B). Our observations are in agreement with certain data from the literature. A similar behavior of the biomimetic apatite that restricted spreading and promoted extension of cellular projections of MC3T3E1 preosteoblasts, along the textured surfaces, was

Table 1 The chemical elemental content of the studied samples (EDX analysis)

\begin{tabular}{cccc}
\hline $\begin{array}{c}\text { Chemical } \\
\text { element }\end{array}$ & $\begin{array}{c}\text { Ti control } \\
\text { (A\%) }\end{array}$ & $\begin{array}{c}\text { Ti infiltrated with } \\
\text { HA (A\%) }\end{array}$ & $\begin{array}{c}\text { Ti infiltrated with } \\
\text { SiO2 (A\%) }\end{array}$ \\
\hline Aluminum & 9.65 & 1.42 & 4.46 \\
Niobium & 3.37 & 0.78 & 1.43 \\
Titanium & 86.98 & 30.25 & 43.65 \\
Phosphorus & & 7.37 & \\
Calcium & & 17.04 & \\
Silicon & & & 6.99 \\
\hline
\end{tabular}

Legend: HA- hydroxyapatite, SiO2- silicatitanate. observed through confocal microscopy by Chou et al. [33]. In a comparative study of the attachment of osteoblastic cells on titanium and hydroxyapatite, Goto et al. [34] found more osteoblasts attached on HA surface which did not form well-defined and polarized stress fibers or vinculin-positive focal adhesions (as did those cultivated on Ti surface).

A quantitative morphometric analysis of cell adhesion was also performed on cells stained with DAPI (for nuclei) and TRITC phalloidin (for actin F). The images were captured with a CCD camera (Axiocam MRM) adapted to a Zeiss Axio Observer D1 inverted microscope and analysed using Axiovision Release 4.6.3. software. The software was calibrated to measure actual dimensions for the $10 \times$ objective lens using a stage micrometer. Adherent cells were observed on the surface of plastic dishes (negative control) and on all titanium implants in a similar number. Positive control consisting by resins compound discs did not allow cells attachment (Figure 3).

Cells were counted in 3 different microscopic fields, through random selection. Using the unpaired $t$ test with Welch's correction we found statistically significant differences between the Ti Ctrl and the other implants ( $\mathrm{Ti} \mathrm{HA}, \mathrm{Ti}_{\mathrm{SiO}_{2}}$ and positive control) with the first more intensely promoting cell attachment in the first hour (Figure 4).

Osteoblast adhesion at two hours and their proliferation at 24 hours, 9 days and 18 days were evaluated using the Alamar blue assay. The results are illustrated in Figure 5 and they show a similar ability of all implants to induce cell adhesion early after seeding.

The differences between the Alamar blue test results and cell count results can be explained by the fact that Alamar blue test incorporates a fluorometric/colorimetric REDOX indicator based on detection of innate cellular metabolic activity. Another possible explanation is that the cells were counted at 1 hour after seeding and the viability test was performed at 2 hours, and this period of 


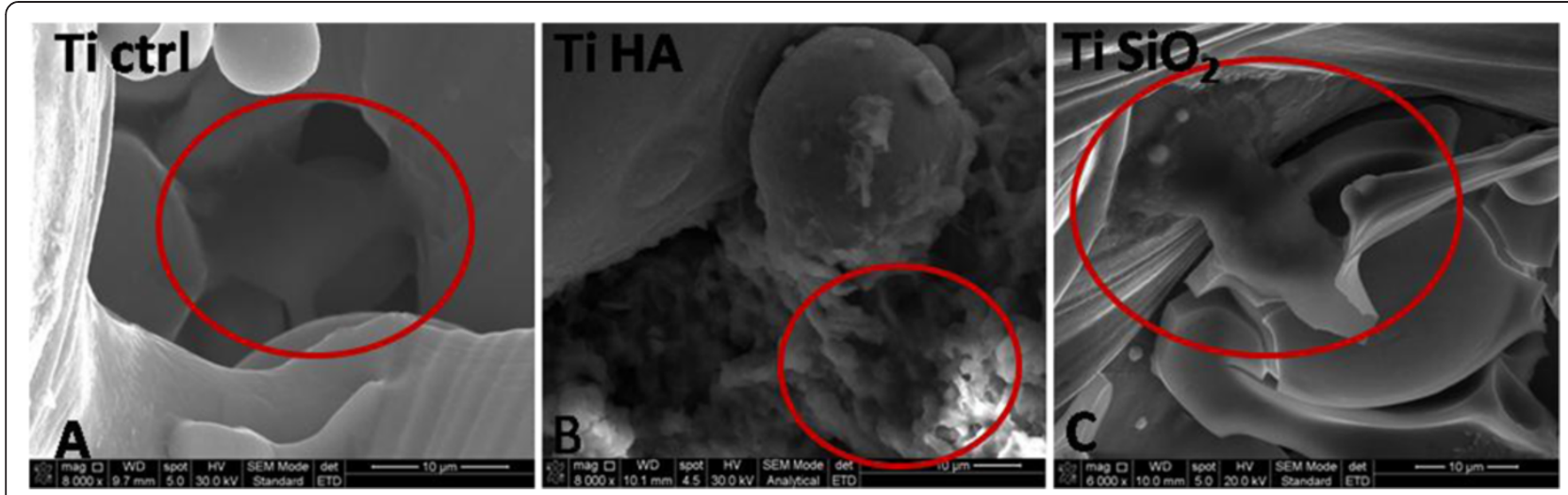

Figure 2 SEM images of the of studied substrates 1 hour after seeding with osteoblasts, showing cells attached to the surface of the implants. Legend: A. non-infiltrated titanium, Ctrl Ti (magnification 8000x); B. titanium infiltrated with hydroxyapatite, Ti HA (magnification 8000x); C. titanium infiltrated with silicatitanate, $\mathrm{Ti} \mathrm{SiO}_{2}$ (magnification 6000X).

time was probably decisive for the completion of cell adhesion on Ti HA implants. In some experimental models it was shown that certain reductases involved in the reduction of Alamar blue are present not only in mitochondria, but in subcellular components and Alamar blue reduction may signify an impairment of cellular metabolism [35]. Some interactions and assay compatibility problems have been specifically demonstrated in screening bioengineered nanomaterials [36]. Another possible explanation is the integrin-triggered production of reactive oxygen species (ROS) derived from mitochondria by signals generated during the early phase of cell attachment with associated changes in the cytoskeleton and in the phosphorylation levels of several proteins [37].

In our experiments, the statistical analysis with Twoway ANOVA Bonferroni posttests showed a significant increase of sample fluorescence intensity for all Ti implants and controls cells without substrate after 9 days of cultivation, with a significant advantage for $\mathrm{Ti} \mathrm{SiO} 2$ implants. Cell viability decreased dramatically after 18 days, as a possible consequence of the progression of the cells to a more advanced stage of differentiation.

The effect of various substrates and media formulation on cell growth and proliferation was determined by the assessment of the rate of total protein synthesis using the microplate BioRad Protein test. The results are displayed in Figure 6.

In the presence of fetal serum, no significant differences between samples were observed (Figure 6A). Differences emerged when cells were cultivated in serum-free conditions, especially for cells grown on $\mathrm{Ti} \mathrm{SiO} 2$ implants (Figure 6B). Statistical analysis with two-way ANOVA Bonferroni posttest showed significant differences at 28 days, favoring the implants of Ti infiltrated with $\mathrm{SiO} 2(* * * \mathrm{p}<0.001)$.
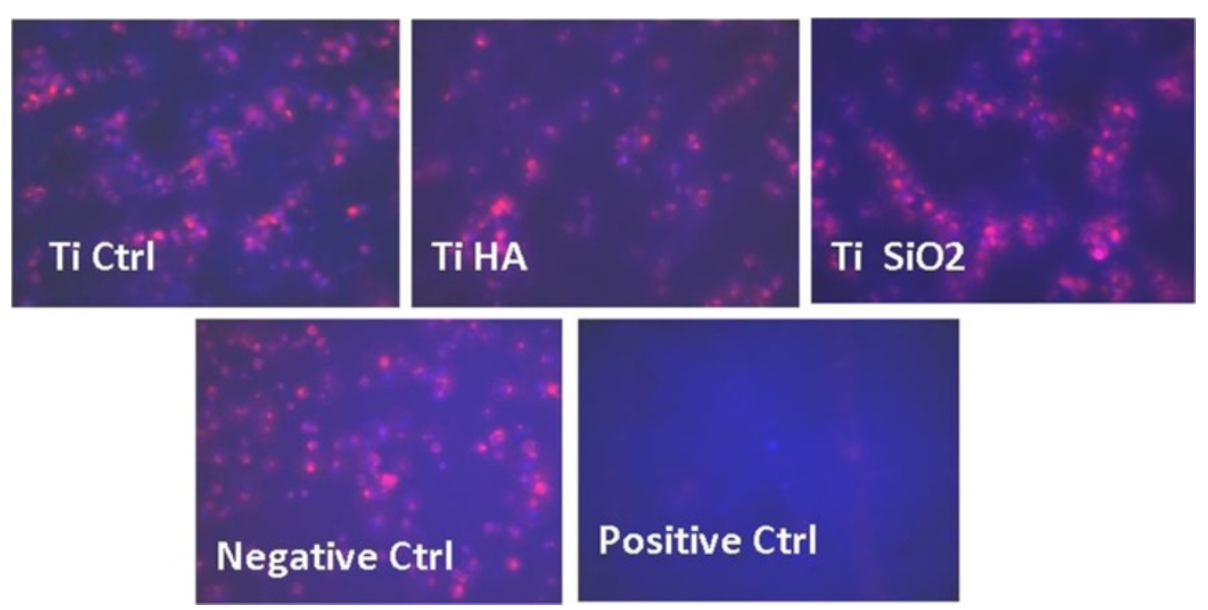

Figure 3 Fluorescence images (magnification 100x) of osteoblasts attached to the surface of the studied implants. Legend: cells cultivated on plastic dihes-negative Ctrl, non-infiltrated titanium Ti Ctrl, titanium infiltrated with hydroxyapatite Ti HA and titanium infiltrated with silicatitanate Ti SiO2, composite resins as positive Ctrl. Staining was made with DAPI (for nuclei, blue staining) and TRITC-phalloidin (for actin F, red staining). 


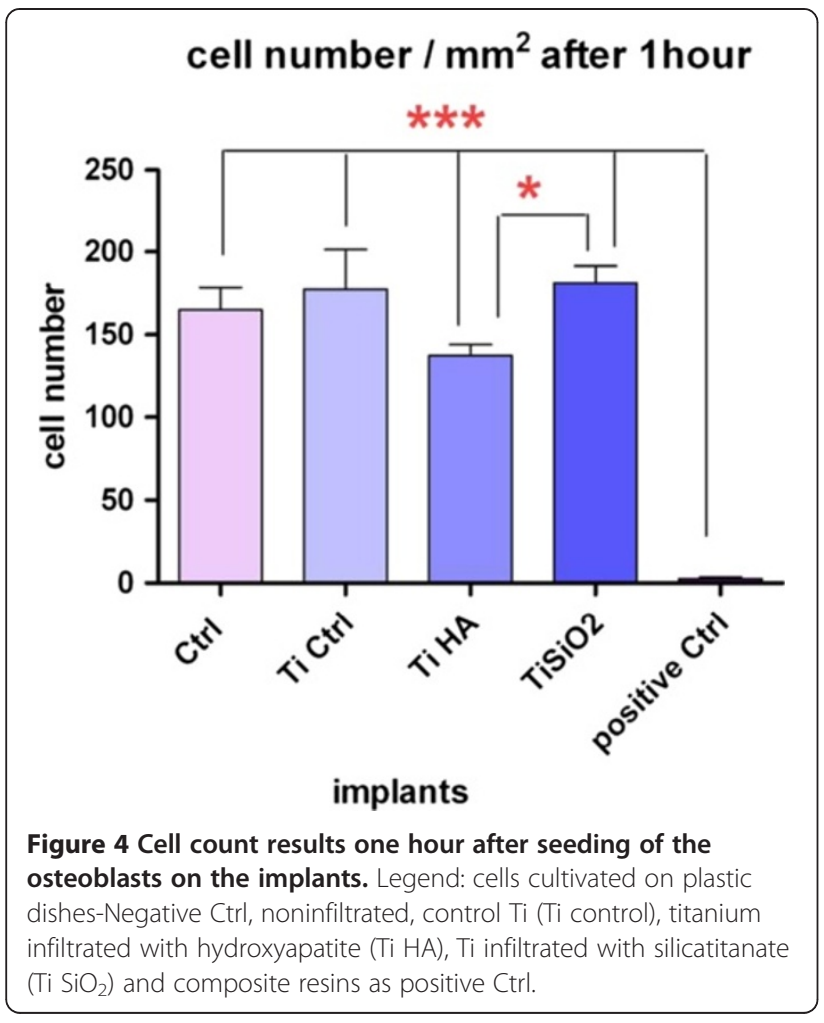

It is known that cellular lysates should reflect the amount of total intracellular proteins. Protein levels were determined in the cellular lysates using the same microplate BioRad Protein assay. We found that the protein levels in the cellular lysates decreased progressively in time in all Ti samples (Figure 7).

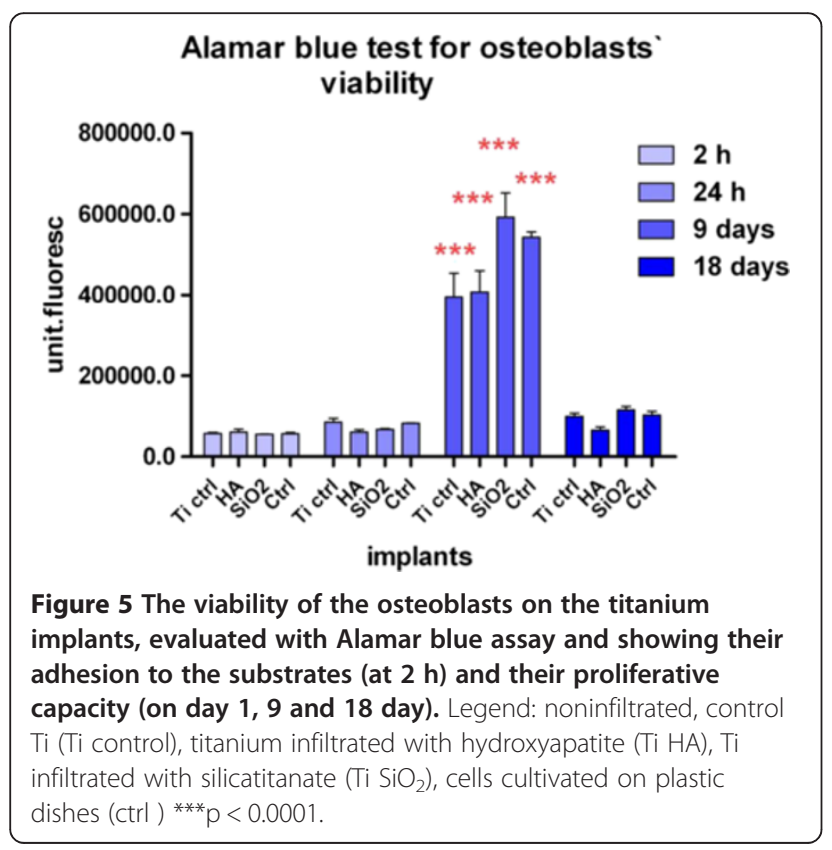

This finding suggests a decreased synthesis of proteins when cells progress in more advanced stage of differentiation, a decrease in cell number (as observed with Alamar test), or both.

\section{Osseoconductivity and osseointegration: osteoblast differentiation and de novo mineralization}

In the present study, OP was determined through an ELISA method both in cell culture medium (complete and serum-free mediums) and in cellular lysate. The evaluations were made in samples harvested at day 8,14 , 21 and 28 in the case of medium with FCS and at day 21 and 28 for serum-free medium. Cell lysates were harvested after 8, 14 and 24 days of cultivation (Figure 8). Medium collected from osteoblasts cultured on plastic dishes was used as for comparison.

One interesting finding is that of consistently higher values of the $\mathrm{OP}$ in samples grown on plastic in the presence of FCS (Figure 8A). One explanation might involve the immobilization of the OP protein in the newly synthesized matrix on Ti implants. We also found differences in OP secretion depending on culture conditions: in simple osteogenic medium, OS (containing $10 \mathrm{nM}$ dexamethasone, $50 \mu \mathrm{g} / \mathrm{ml}$ ascorbic acid and $10 \mathrm{mM} \beta$ glycero-phosphate) or in complex osteogenic medium, OC (supplemented with growth factors: $3 \mathrm{ng} / \mathrm{ml}$ TGF $\beta 1$ and $4 \mathrm{ng} / \mathrm{ml}$ BMP2) (all reagents acquired from Sigma Aldrich). These differentiation-favorable environments induced an increase in the OP level for the Ti Ctrl implants (Figure 8B).

The assessment of OP levels in cell lysates, at 8 and 14 days of culture, showed no differences between substrates (Figure 9).

The expression of OP was also studied in immunostained samples fixed after 3, 14 and 21 days. Each types of implant ( $\mathrm{Ti}$ Ctrl, $\mathrm{Ti} \mathrm{HA}$ and $\mathrm{Ti} \mathrm{SiO}_{2}$ ) showed positivity for OP until day 14, after which the protein expression decreased (Figure 10). This phenomenon can be explained by an earlier initiation of the mineralization process (especially for implants with HA), which could be correlated with the disappearance of OP, as some authors consider $\mathrm{OP}$ as an inhibitor of mineralization [38,39].

For a better visualization of the expression of OP and of cell adhesion to the implants' surface, we used a triple staining with fluorescein isothiocyanate (FITC) for osteopontin expression, phalliodin TRITC for F-actin fibers and DAPI for nuclei (Figure 11).

This triple coloration allowed a more accurate observation of osteoblasts cultured for 14 days on titanium implants. DAPI staining of nuclei showed the number per microscopic field of cells adhered to the implants' surface, with no notable differences between implants. OP protein stained with FITC-conjugated antibodies, showed characteristic intracellular aggregates with increased fluorescence 
Total proteins in medium with FCS

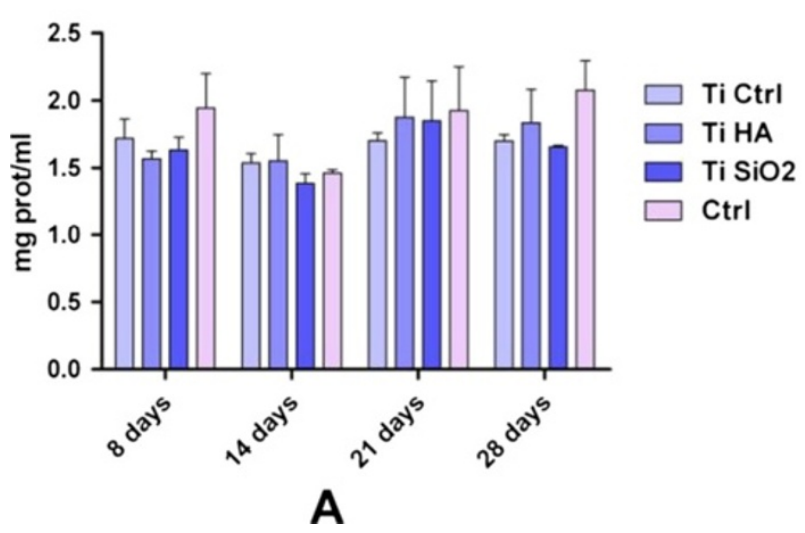

Total proteins in serum free medium

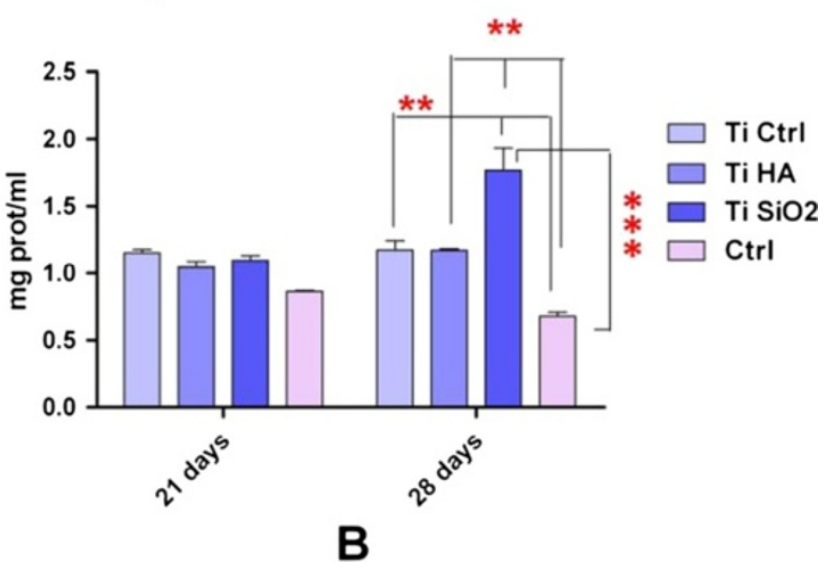

Figure 6 Levels of total proteins secreted in culture mediums by osteoblasts cultivated on the implants' surface, measured with the Bio-Rad protein microplate assay. A. in complete medium with fetal calf serum, FCS (measured on day 8, 14, 21 and 28); B. in serum-free medium (measured on day 21 and 28) Legend: noninfiltrated, control Ti (Ti control), titanium infiltrated with hydroxyapatite (Ti HA), Ti infiltrated with silicatitanate $\left(\mathrm{Ti} \mathrm{SiO}_{2}\right)$, cells cultivated on plastic dishes (ctrl).

intensity in cells cultivated on $\mathrm{Ti} \mathrm{Ctrl}$ and $\mathrm{Ti}_{\mathrm{SiO}}$ implants. Cells grown on the HA implants were probably embedded and masked by HA crystals. Actin filaments (stained with TRITC phalloidin) had a more intensive and obvious expression in the case of control $\mathrm{Ti}$ and $\mathrm{SiO}_{2} \mathrm{Ti}$ implants, as these substrates promoted the adherence of osteoblasts on a larger area while also inducing a flattened shape and the development of dendritic spines. Cells grown on Ti HA had a more compressed cell body with extensions that could not be seen due to the HA layer. In our experiments only $\mathrm{Ti}_{\mathrm{SiO}}$ implants showed expression of stress fibers.

Osseointegration is a later stage in the evolution of an implant and is characterized by the establishment of

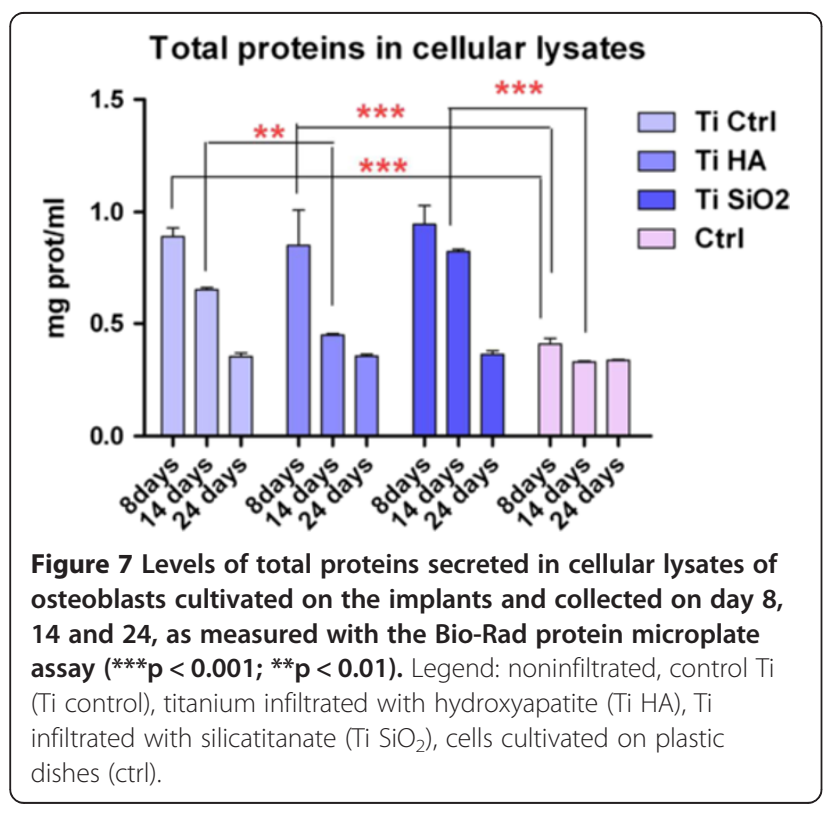

bone-implant contact and the development of peri-implant bone as a consequence of osteogenic mineralization [40]. In the present study, mineralization was assessed by quantifying calcium deposition on Ti implants with a modified Alizarin red method. Evaluations were made in $\mathrm{Ti}$ implants seeded with osteoblasts, after 14, 21 and 28 days of cultivation in medium with FCS or serum-free medium. Because Ti HA implants contain large amounts of calcium, we assessed the amount of calcium in Ti HA implants without cells growing on their surface and the results were subtracted from those obtained for Ti HA implants cultivated with cells.

In the first 14 days an equal amount of calcium was observed in all titanium implants, when cultivated in complete medium. After 21 and 28 days of cultivation in complete medium, a gradual increase in calcium deposits occurred mostly in Ti HA implants and, in a lower degree, in $\mathrm{Ti} \mathrm{SiO}_{2}$ implants. Serum-free medium significantly increased the deposition of calcium on the surface of Ti HA implants and on control samples after 28 days of cultivation (Figure 12).

Evaluation of alkaline phosphatase (ALP) activity in the environment of osteoblasts cultured on $\mathrm{Ti}$ implants revealed different cell behaviors depending on the type of cultivation medium (medium with FCS, serum-free medium, simple osteogenic and complex osteogenic differentiation medium), culture duration and the type of titanium implants (Figure 13). The highest levels of ALP activity were obtained in Ti Ctrl implants and controls without substrate after 14 days of cultivation in complete medium and for $\mathrm{Ti} \mathrm{SiO}_{2}$ implants after 21 days (Figure 13A). (Two-way ANOVA Bonferroni posttest; *** $\mathrm{p}<0.01$ ). A common trend of progressive decline in ALP activity was observed after 28 days. In serum-free 


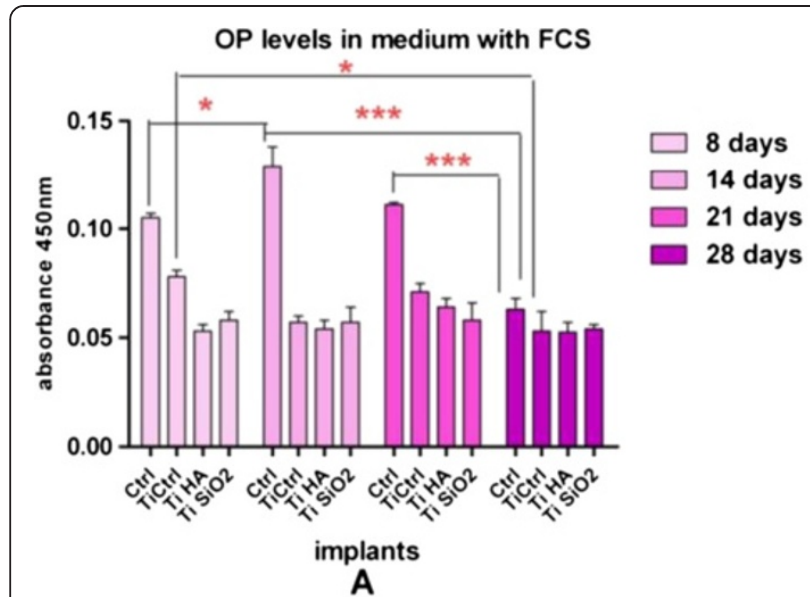

OP levels in serum-free and differentiation medium

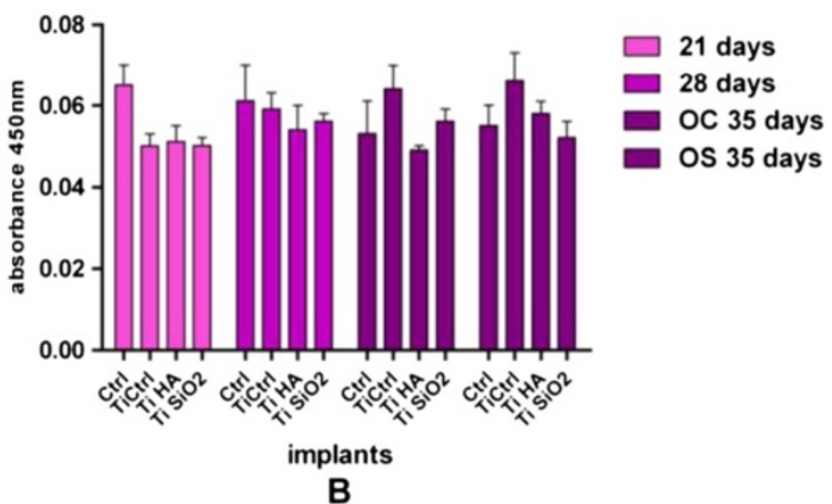

B

Figure 8 Levels of osteopontin (OP) secreted in the culture medium by osteoblasts cultured on the implants' surface. A. in medium wih fetal calf serum (FCS), collected on day 8, 14, 21 and 28 (analysis with two-way ANOVA Bonferroni posttest ${ }^{*} \mathrm{p}<0.05 ;{ }^{* *} \mathrm{p}<0.01 ;{ }^{* * *} \mathrm{p}<0.001$ ); B. in serum-free medium (collected on day 21 and 28), in simple (OS) and in complex (OC) differentiation mediums (collected on day 35). Legend: cells cultivated in plastic dishes (ctrl), non-infiltrated, control Ti (Ti control), titanium infiltrated with hydroxyapatite (Ti HA), Ti infiltrated with silicatitanate $\left(\mathrm{Ti} \mathrm{SiO}_{2}\right)$.

conditions ALP activity increased significantly after 21 days in $\mathrm{Ti} \mathrm{SiO}_{2}$ implants, and after 35 days in $\mathrm{Ti} \mathrm{Ctrl}$ and Ti HA implants as well control samples in simple osteogenic medium (Figure 13B). (Two-way ANOVA Bonferroni posttest; " $\mathrm{p}<0.05$; *** $\mathrm{p}<0.01$ ).

ALP activity was also evaluated in cellular lysates obtained after 8 and 14 days of osteoblast cultivation. The results showed higher levels of the enzyme in cellular lysates when compared with the complete medium-derived samples. At 14 days, the highest ALP activity was found in the lysates obtained from the cells cultivated on $\mathrm{Ti}_{\mathrm{SiO}}$ implants (Figure 14).

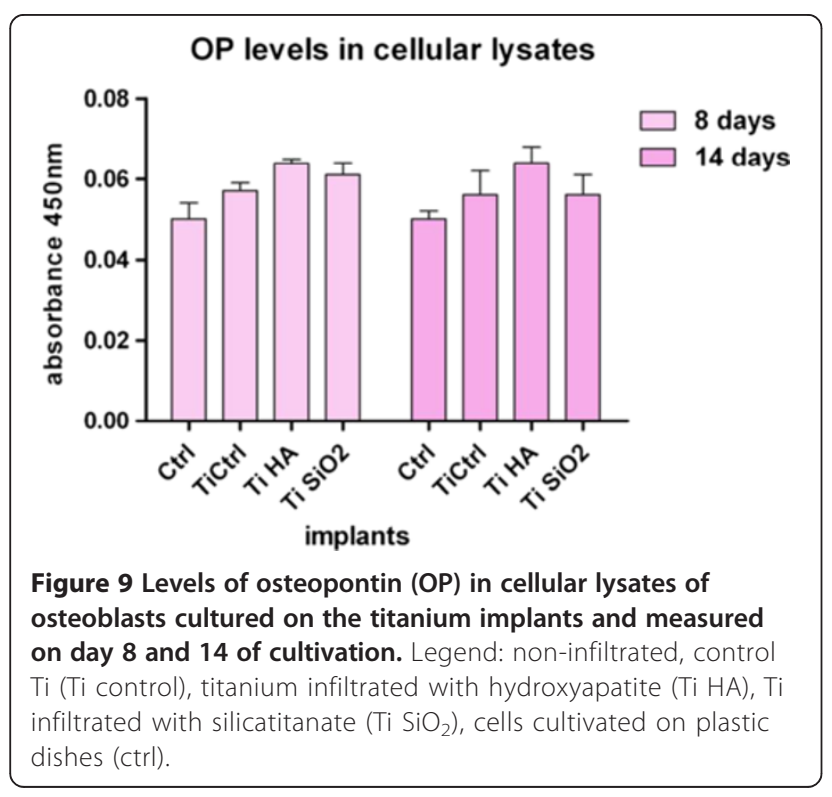

\section{Collagen detection}

Levels of the most abundant protein of the extracellular matrix, collagen, were determined with the SIRCOL collagen assay, in samples cultured in serum-free medium (SF), simple osteogenic medium (OS) and complex osteogenic differentiation medium (OC). Medium was harvested on day 21 and 28 (for the serum-free medium) and on day 35 (for the two differentiation mediums). In the serum free medium, an important increase in soluble collagen concentration was seen on day 28 (compared with day 21) for the $\mathrm{Ti} \mathrm{SiO}_{2}$ implants (Figure 15). The results also showed significant differences between culture mediums with respect to their content in soluble collagen, as one-way ANOVA tests showed. Notable differences were observed between all samples of $\mathrm{Ti}$ implants and control without substrate cultivated in medium with FCS and samples cultivated 28 and 35 days in simple osteogenic medium (OS) and complex osteogenic medium (OC). Analysis with two-way ANOVA Bonferroni posttest; "p $<0.05$ showed a significant increase of soluble collagen in control samples after 35 days of cultivation in OC medium (Figure 15).

Collagen secretion was also investigated by immunocytochemical staining of cells grown on titanium samples. Type I collagen was expressed by all samples grown on titanium, with a higher observed intensity in control $\mathrm{Ti}$ and $\mathrm{Ti}$ infiltrated with $\mathrm{SiO}_{2}$ after 14 days and much more intensely after 28 days of cultivation (Figure 16).

The osteoblast-osteocyte transition was observed after 28 days of cultivation especially on titanium samples with $\mathrm{SiO}_{2}$ and in a lower degree on control titanium-cultured samples. This was suggested by the strong expression of osteocalcin, as revealed through immunocytochemical staining. In silicatitanate- and HA-infiltrated implants, 

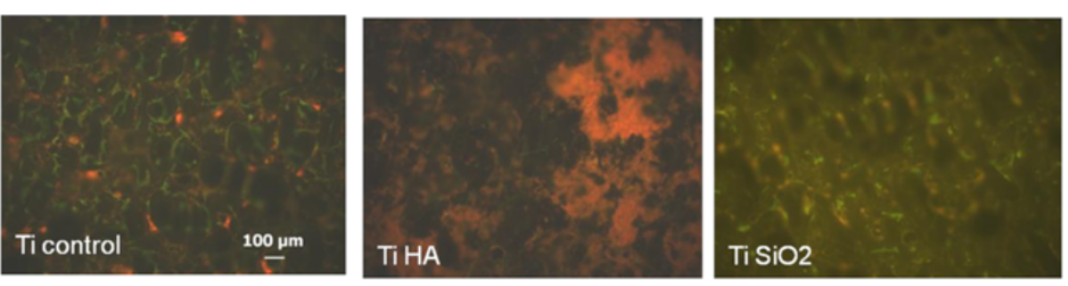

3 days
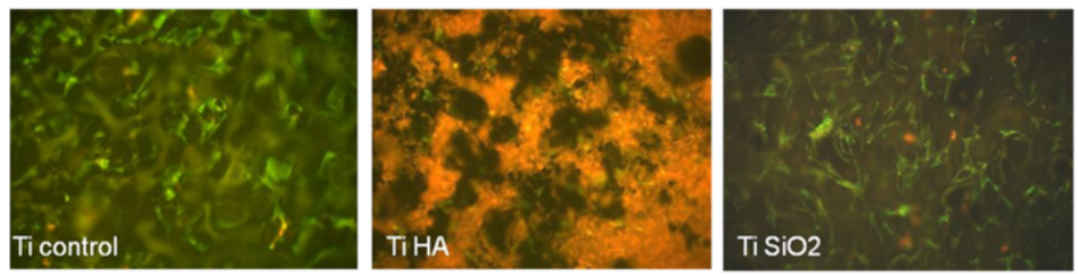

14 days
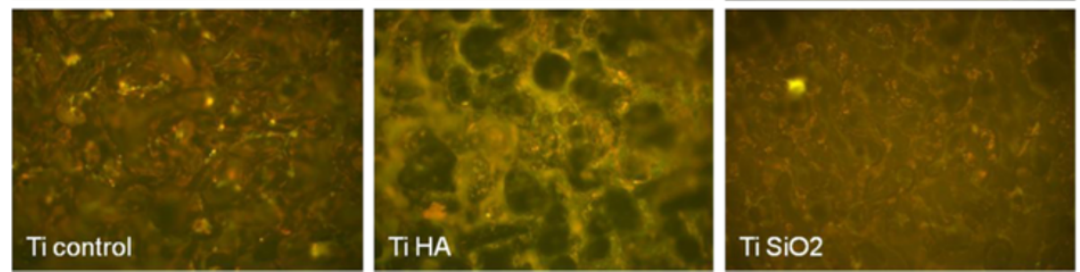

21 days

Figure 10 Immunocytochemical staining of the osteoblasts cultivated on the surface of the implants showing the expression of osteopontin (OP). Osteoblasts were stained with an anti OP-FITC monoclonal antibody on day 3, 14 and 21 days (magnification 100x). Legend: non-infiltrated control $\mathrm{Ti}$ (Ti control), titanium infiltrated with hydroxyapatite ( $\mathrm{Ti} \mathrm{HA}$ ), Ti infiltrated with silicatitanate $\left(\mathrm{Ti} \mathrm{SiO}_{2}\right.$ ).

deposition of osteocalcin seems to occur in the extracellular matrix, with a more uniform distribution of the protein observed in the case of $\mathrm{SiO}_{2}$ implants. In comparison, in control titanium implants osteocalcin was located in the intracellular space of the osteoblasts (Figure 17).

SEM images taken after 28 days show various obvious morphological changes of cells depending on the type of implant. A typical osteocytic morphology - with long dendrite-like processes interacting with neighboring cells was observed mainly on the $\mathrm{SiO}_{2}$ surface implant and to a lesser extent in control titanium (Figure 18A and $\mathrm{C}$ ). $\mathrm{Ti}$
HA implants had a more particular morphology: the cells appeared to be partially included in the HA and in the newly formed matrix substrate. The cell extensions were also likely to be masked (Figure 18B).

\section{Discussions}

Osseoinduction, osteoconduction and osseointegration are the three interdependent steps involved in bone healing, and the specific response of the bone to implant insertion is similar to its response to fractures [41]. Osseoinduction - defined by Friedenstein in 1968 as the recruitment of undifferentiated osteoprogenitor cells and
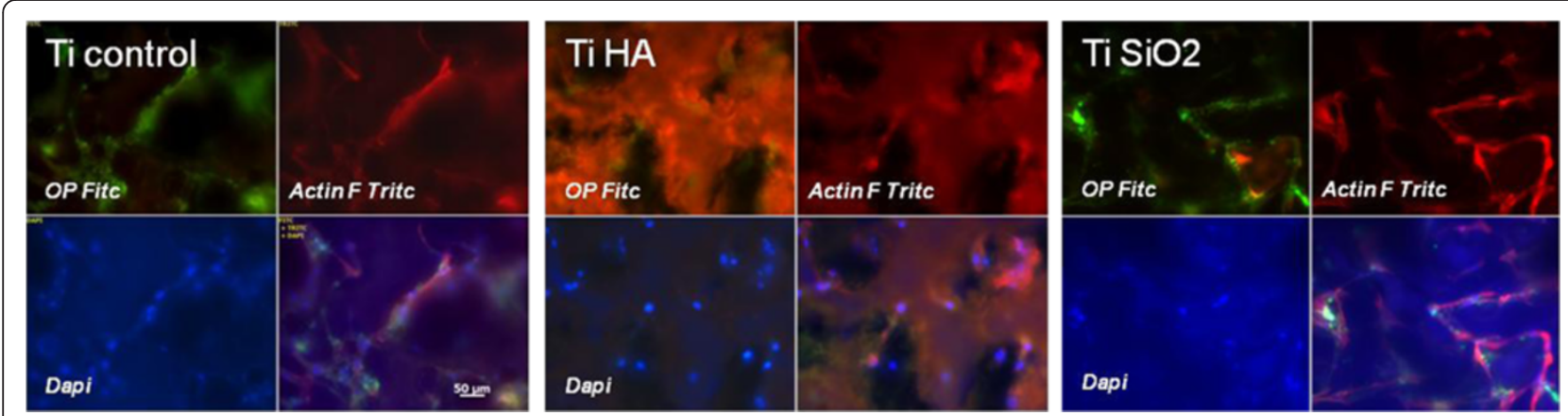

Figure 11 Immunocytochemical staining of osteoblasts on the surface of the implants (noninfiltrated Ti, Ti infiltrated with $\mathrm{HA}$ and $\mathrm{Ti}$ infiltrated with $\mathrm{SiO}_{2}$ ) showing the expression of actin $\mathrm{F}$ and osteopontin (OP). Osteoblasts were stained with anti OP-FITC monoclonal antibody, phalloidin TRITC (for actin F) and DAPI (for nuclei). The images were taken on day 14 and composed with Axiovision Release 4.6.3. image analysis software (magnification 200X). Legend: non-infiltrated, control Ti (Ti control), titanium infiltrated with hydroxyapatite (Ti HA), Ti infiltrated with silicatitanate $\left(\mathrm{Ti}_{\mathrm{SiO}}\right)$. 


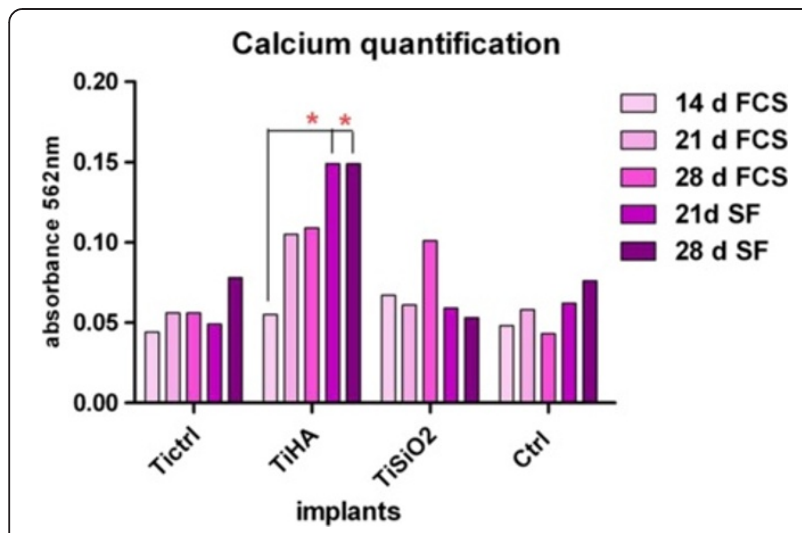

Figure 12 Levels of calcium deposition on the implants by osteoblasts cultured in medium with fetal calf serum, FCS (measured on day 14, 21 and 28) and in serum-free medium, SF (measured on day 21 and 28). Quantification of the Calcium content was done using a modified Alizarin red method. Legend: noninfiltrated, control $\mathrm{Ti}$ ( $\mathrm{Ti}$ control), titanium infiltrated with hydroxyapatite (Ti HA), Ti infiltrated with silicatitanate $\left(\mathrm{Ti} \mathrm{SiO}_{2}\right)$, cells cultivated on plastic dishes (ctrl).

their induction into osteogenic competent cells - depends mainly on cell adhesion phenomena [42,36]. The quality of the interface between cells and implants is essential for the induction of events involved in implant integration [43]. The adhesiveness of bone grafts/implants is related to their ability to support selective attachment, proliferation, differentiation and migration of anchorage-dependent cells [44]. Some examples of osseoinductive materials used as implants are: the polymer polyhydroxyethylmethacrylate (poly-HEMA), metals (porous titanium), natural materials such as hydroxyapatite (HA), synthetic ceramics and composites such as HA/poly(lactic-coglycolic acid) (PLGA) or HA/collagen [2].

The aim of this study was to compare the osseoinductive, osteoconductive and osseointegrative properties of two kinds of titanium implant coatings, with the purpose of selecting materials with increased bioactivity. Ti6Al7Nb implants with $25 \%$ total porosity, processed with SLM technology, were infiltrated with hydroxyapatite and silicatitanate through a sol-gel method. Gravimetric method revealed a slow decrease of porosity to $22 \%$ for Ti HA implants and to $23 \%$ for $\mathrm{Ti}_{\mathrm{SiO}}$. Uncoated $\mathrm{Ti}$ implants were used as controls. SEM and EDX analysis revealed that the two methods of coating conferred, as expected, different physical and chemical properties. For the Ti Ha implants, the EDAX analysis resulted in $30.25 \% \mathrm{Ti}$ content (A\%) with a $\mathrm{Ca} / \mathrm{P}$ ratio of 2.3 . The attachment of cells on the $\mathrm{Ti}$ HA scaffolds was delayed in the first hour when compared to $\mathrm{Ti}_{\mathrm{SiO}_{2}}$ and porous uncoated $\mathrm{Ti}$ implants, as revealed by SEM images and cell counting. However, this initial disadvantage was subsequently surmounted, as evidenced by the assessment of proliferation with Alamar blue and total protein content. The metabolic activity of osteoblasts was highest after 8-9 days of cultivation in all Ti implants, with an observed advantage in $\mathrm{SiO}_{2}$ infiltrated $\mathrm{Ti}$ implants. This advantage was maintained until day 28 , as proved by the increasing protein content in serum-free medium. Similar results were obtained by Waselau et al. [45] in a comparative study analyzing the effects of bioactive glass $\mathrm{S} 53 \mathrm{P} 4$ and beta-tricalcium phosphate on osteogenic differentiation of human adipose stem cells in the presence of BMP-2 and BMP-7. qDNA measurements revealed significantly greater cell populations in the case

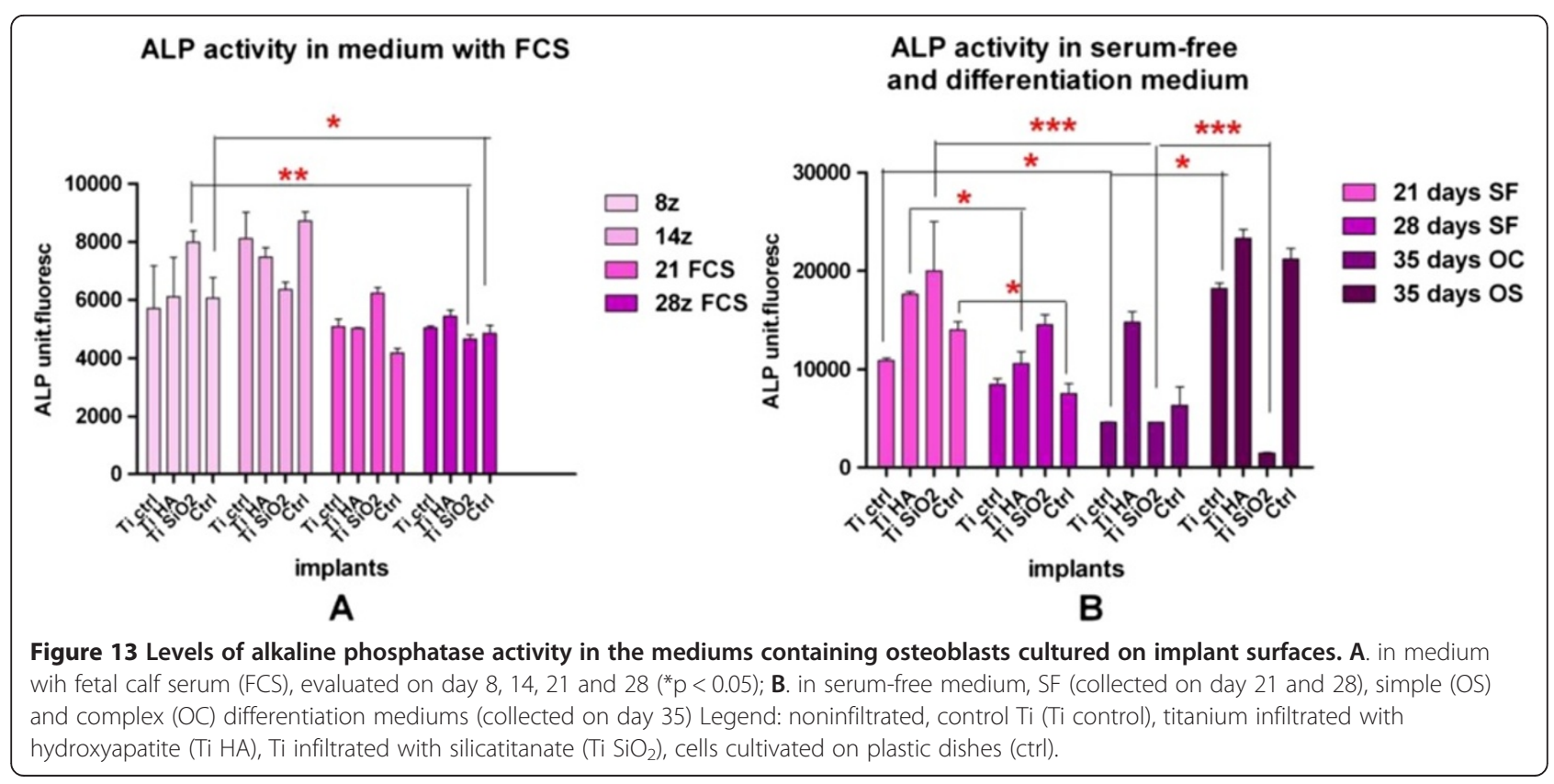




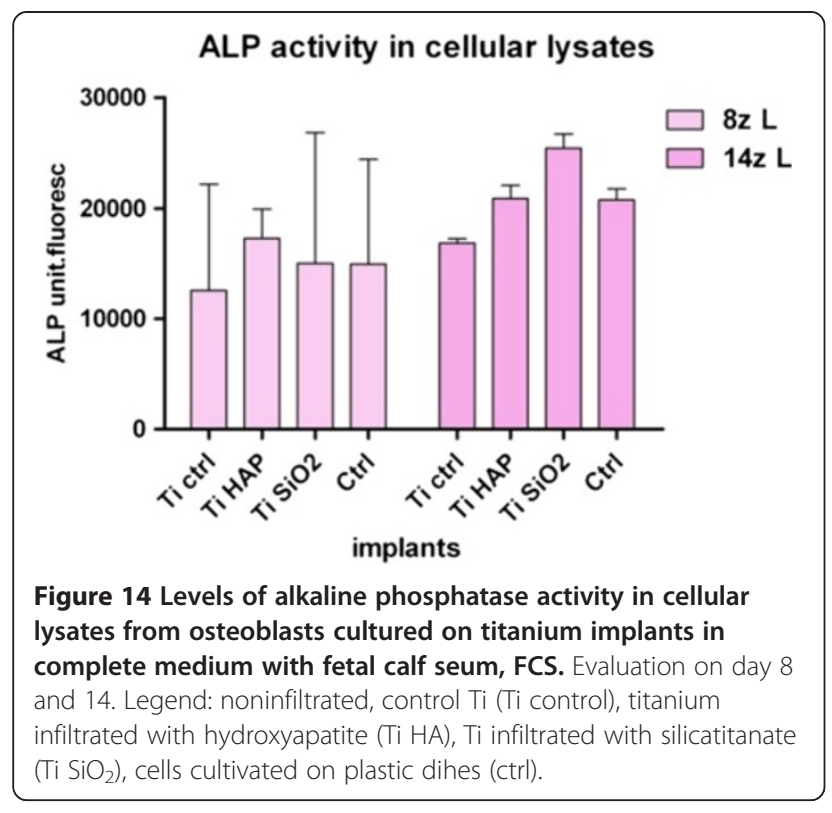

of bioactive glass used with control medium after 7 days and in osteogenic medium after 14 days [45].

The HA coatings are biomimetic and many studies proved their osteoconductivity. On the other hand, their osseoinductive ability is more controversial and still highly debated. This may be due to differences in the manufacturing process, which result - even in case of equal chemical compositions - in different levels of microporosity and surface roughness, which are essential factors that determine the osseoinductive potential of the material $[42,36]$.

The silicatitanate gel used for Ti coating in our experiments contained $6.99 \%$ silica and demonstrated a good osteoinductive activity, sustaining cell adhesion and proliferation. The sol-gel method used for obtaining this coating is now preferred to the classical melting method because of its advantages [46]. It is a much more flexible method for obtaining amorphous multicomponent oxide systems of high purity and homogeneity, at lower temperatures, with a controlled porosity [47]. By forming nanopores in the glass, the surface area becomes enlarged and provides sites for cell attachment $[48,49]$. Also, the hydroxyl groups located in the sol-gel of bioactive glasses structures confer a higher bioactivity when compared to the bioactive glasses prepared by melting techniques. In addition, by releasing soluble silica and calcium ions, it promotes differentiation of osteoprogenitor cells [50,51]. Many in vitro studies investigated the role of silicon $(\mathrm{Si})$ in bone homeostasis and reported that $\mathrm{Si}$ increased the synthesis of non-collagenous matrix polysaccharides and of collagen, due to increased prolylhydroxylase activity (the enzyme involved in collagen synthesis). Si also exerts a direct influence on osteoblasts, promoting cell proliferation, extracellular matrix synthesis, alkaline phosphatase (ALP) activity and osteocalcin synthesis [52].

Osteoconductive materials allow bone growth on the surface of materials and into their pores, channels or pipes, which also depends on previous osseoinduction and on proper blood supply. Signals from cells adhered to the biomaterial's surface trigger the secretion of many growth factors with mitogenic and angiogenic activity, such as: insulin-like growth factors I and II (IGF I, II), fibroblast growth factor (FGF), transforming growth factor (TGF- $\beta$ ), vascular endothelial growth factor (VEGF) and platelet-derived growth factor (PDGF), as well as the secretion of bone tissue-related growth factors with osteogenic potential: bone morphogenic proteins 2 and

\section{Levels of soluble collagen-SIRCOL assay}
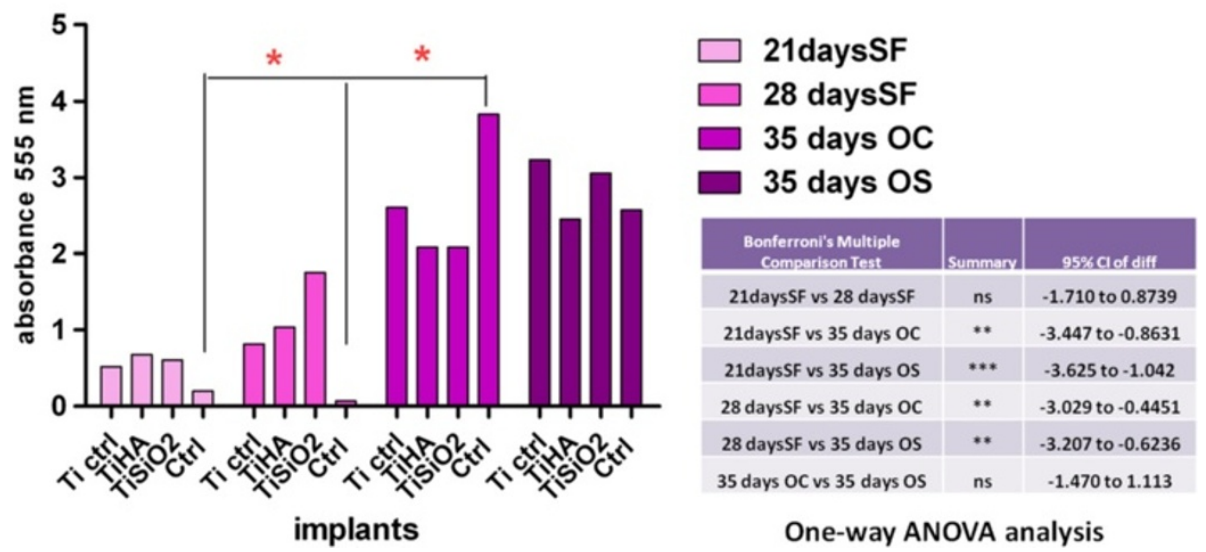

Figure 15 Levels of soluble collagen produced by the osteoblasts cultured on titanium implants in serum-free medium (collected on day 21 and 28), simple (OS) and complex (OC) differentiation mediums (collected on day 35). Legend: noninfiltrated, control Ti (Ti control), titanium infiltrated with hydroxyapatite (Ti HA), Ti infiltrated with silicatitanate $\left(\mathrm{Ti} \mathrm{SiO}_{2}\right)$, cells cultivated on plastic dihes (ctrl) Table: One-way ANOVA analysis reveals statistical differences between the medium of cultivation (SF vs. OS and OC serum-free medium). 

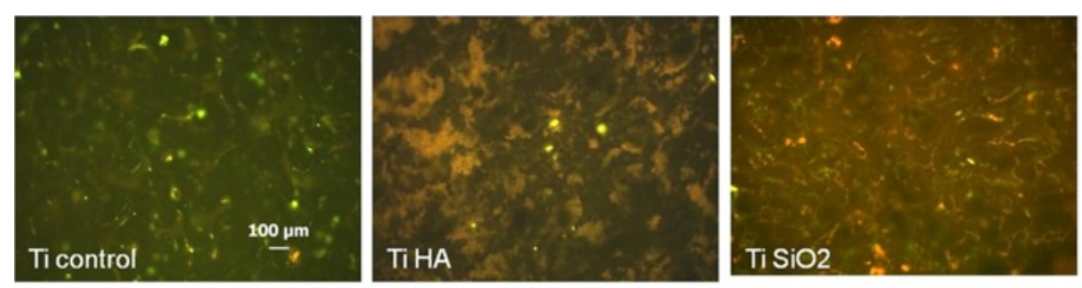

14 days
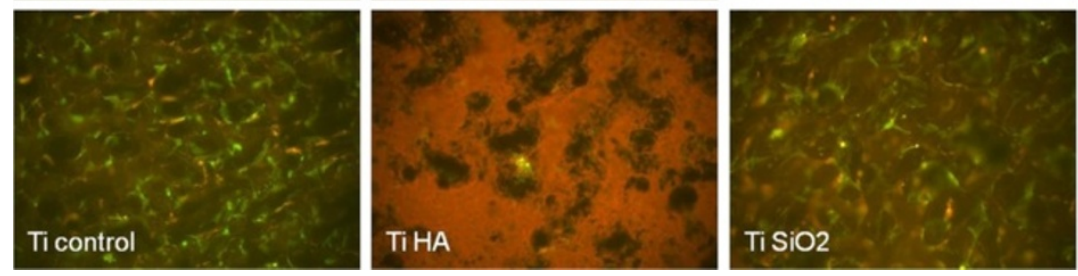

28 days

Figure 16 Immunocytochemical staining (FITC) for collagen 1A of the osteoblasts cultured in complete medium on titanium implants and evaluated on day $\mathbf{1 4}$ and 28. Legend: noninfiltrated control Ti (Ti control), titanium infiltrated with hydroxyapatite (Ti HA), Ti infiltrated with silicatitanate $\left(\mathrm{Ti} \mathrm{SiO}_{2}\right)$ (magnification 100X).

7 (BMP-2 and BMP-7) [3,45]. Osseointegration allows bone anchorage and consolidation between the newly formed bone and the implant. Because initial osseointegration is dependent on bone induction and conduction, materials that are too toxic to allow cellular adhesion and development into bone forming cells will not be osseointegrated [3]. Formation of hydroxyapatite and surrounding bone tissue by binding to the extracellular matrix is essential for osseointegration. The most important questions to answer when investigating a system of osteoblasts cultured on implants are whether the substrate supports de novo matrix mineralization, if it is similar to its naturally occurring counterpart, and how it could be distinguished from the presence of minerals contained in the substrate.

Osteoconductivity and osseointegration of $\mathrm{Ti} \mathrm{HA}, \mathrm{Ti}$ $\mathrm{SiO}_{2}$ and porous $\mathrm{Ti}$ implants used in the present study were evaluated by assessing the differentiation and mineralization processes. Osteopontin (OP) is one of the most important non-collagenous phosphoproteins and an indicator of the differentiation process of osteoblasts.
OP expression was evaluated in different culture media (complete medium, serum-free medium and osteogenic medium) at different points in time. Using the ELISA method, no significant differences were found among the implants. Interestingly, the highest OP values were detected on day 14, for the cultures grown in complete medium on plastic dishes. This may be explained by the immobilization of OP on the implant surface in the newly synthesized matrix, as OP was reported to be present both in an immobilized form in the extracellular matrix of mineralized tissues and in a soluble form in tissue fluids $[53,54]$. The osteogenic differentiation medium induced a discrete increase in OP levels after 35 days of osteoblast cultivation on control Ti implants. A strong OP expression, evaluated by immunocytochemical staining, was detected after day 3 for $\mathrm{Ti} \mathrm{Ctrl}$ and $\mathrm{Ti} \mathrm{SiO}_{2}$ implants. It continued to increase until day 14 and decreased after 21 days. With a combined immunostaining for osteopontin and filamentous actin, different behaviors of implants were observed with regard to the rearrangement of actin fibres. The $\mathrm{Ti} \mathrm{SiO}_{2}$ and $\mathrm{Ti} \mathrm{Ctrl}$ implants induced a more

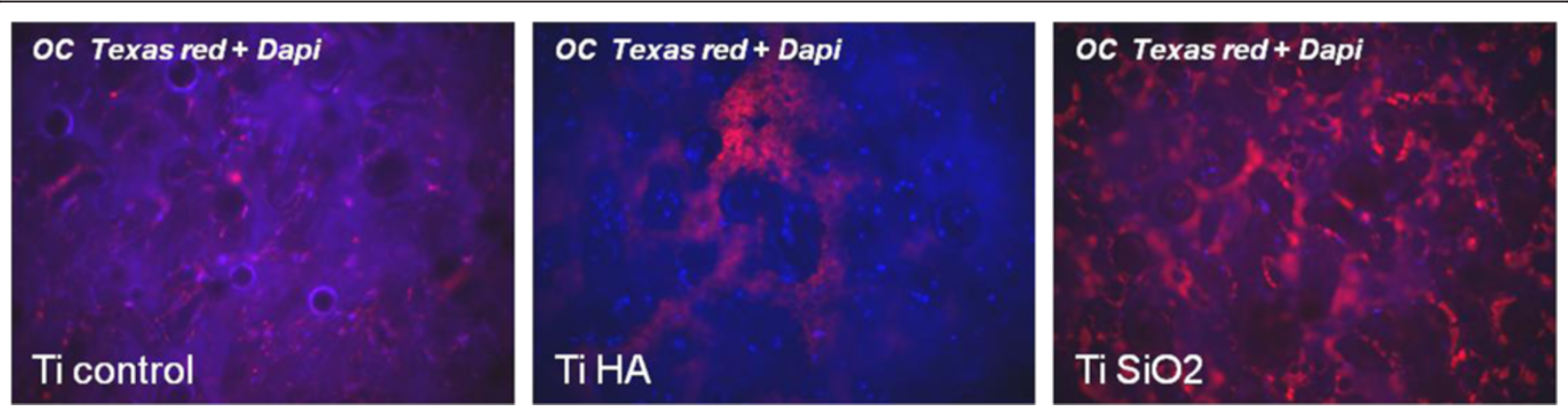

Figure 17 Immunocytochemical staining for osteocalcin Texas red, counterstained with DAPI in osteoblasts cultured in complete medium on titanium implants evaluated after $\mathbf{2 8}$ days of cultivation. Legend: non-infiltrated, control Ti (Ti control), titanium infiltrated with hydroxyapatite ( $\mathrm{Ti} \mathrm{HA})$, Ti infiltrated with silicatitanate $\left(\mathrm{Ti} \mathrm{SiO}_{2}\right)$ (magnification 100x). 

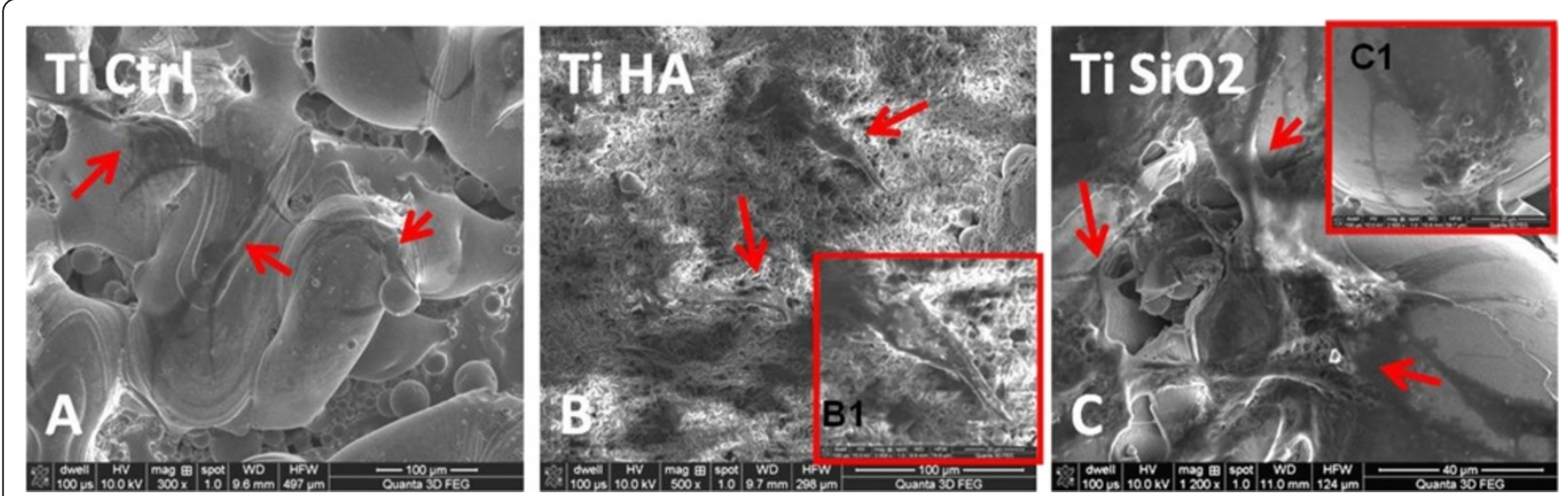

Figure 18 Scanning electron microscopy images of osteocytes attached to the surface of titanium implants after 28 days of cultivation. Legend: Osteocytes are indicated by arrows. A. noninfiltrated control Ti (magnification $\times 300)$; B. Ti infiltrated with hydroxyapatite

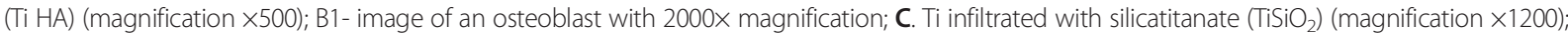
C1- image of an osteocyte with $\times 2500$ magnification.

flattened morphology of cells, and were associated with the expression of stress fibers.

The actin cytoskeleton is involved in cell adhesion and cell motility, and its fiber arrangement modulates cell shape differently depending on the type of nanoscale and microscale surface roughness as well as the patterning of the surface of the material on which cells are grown. Mechanical stimulation of osteoblasts or stem cells induced by the properties of the implant surface triggers the reorganization of the focal adhesion plaques followed by the rearrangement of the cytoskeleton and the activation of signaling pathways involved in osteogenic cell differentiation such as transcription factors Cbfa1 (Core Binding Factor A1) and Osterix. As a consequence osteoblasts synthesize higher amounts of collagen I, osteopontin, osteocalcin and bone sialoprotein, and induce higher levels of alkaline phosphatase activity [55-57]. The canonical Wnt (Wingless/Integrated) signaling pathway is also activated with consequences on $\beta$ catenin, alkaline phosphatase and osteocalcin expression, as Galli et al. showed in a study using mesenchymal and osteoblastic cells growing on polished titanium discs versus acid-etched and sand-blasted (SLA) surfaces. Differences were also observed among various cell types [58]. For instance, OP is also involved in cell adhesion phenomena of cell-cell or cell-extracellular matrix interactions that occur during cell proliferation and migration. Elevated concentrations of osteopontin were found in sites of bone resorption and its expression was strongly increased by mechanical stimuli. The effects of OP on HA formation seem to be related to its phosphorylation state. Exogenous phosphorylated OP is known to inhibit mineralization, but dephosphorylation by tissue-nonspecific alkaline phosphatase (ALP) reverses this effect [38,39]. The phosphorylation state of OP can be influenced by the physical and chemical properties of the substrate and, as a consequence, modulates its signaling ability [59]. This fact may explain the different cell responses observed in our experiments, most notably the increased expression of OP in complete medium after 8-14 days especially in $\mathrm{SiO}_{2} \mathrm{Ti}$ and control Ti implants, which correlates with concomitant increases of other specific proteins such as ALP.

ALP is a key enzyme that can both promote and inhibit mineralization. It is a cell-membrane-associated enzyme, expressed also in matrix vesicles, and in association with other proteins enhances deposition of hydroxyapatite along the collagen fibrils. ALP hydrolyzes its substrate, inorganic pyrophosphate, to inorganic phosphate, the latter being a substrate for the HA mineral [60]. In our experiments, the highest activity of ALP was found in the samples obtained from the lysate of cells cultivated on $\mathrm{Ti} \mathrm{SiO}_{2}$ implants. However, the activity of ALP was much higher (2-2.5 fold) in serum-free conditions, especially in Ti HA and $\mathrm{SiO}_{2}$ implants. ALP activity decreased rapidly after 28 days, indicating that the mineralization process is nearly complete. In osteogenic differentiation mediums, the expression profile of ALP was different. A strong ALP activity was detected on day 35 in simple osteogenic medium from the Ti Ctrl and Ti HA, accompanied by elevated levels of collagen. $\mathrm{SiO}_{2}$ implants did not respond to the differentiation medium in terms of ALP activity, but exhibited similar levels of collagen. The presence of BMP2 and TGF $\beta 1$ in the complex osteogenic medium increased ALP activity only in Ti HA implant cultures (Figure 19).

Collagen synthesis, as an indicator of matrix formation, was significantly increased in $\mathrm{Ti}_{\mathrm{SiO}}$ samples after 28 days. In addition, higher soluble collagen levels were observed in control $\mathrm{Ti}$ and $\mathrm{Ti} \mathrm{SiO}_{2}$ implants cultivated in simple osteogenic differentiation medium. These findings do not exclude possibly similar collagen synthesis on Ti HA implants, yet we could not demonstrate this 


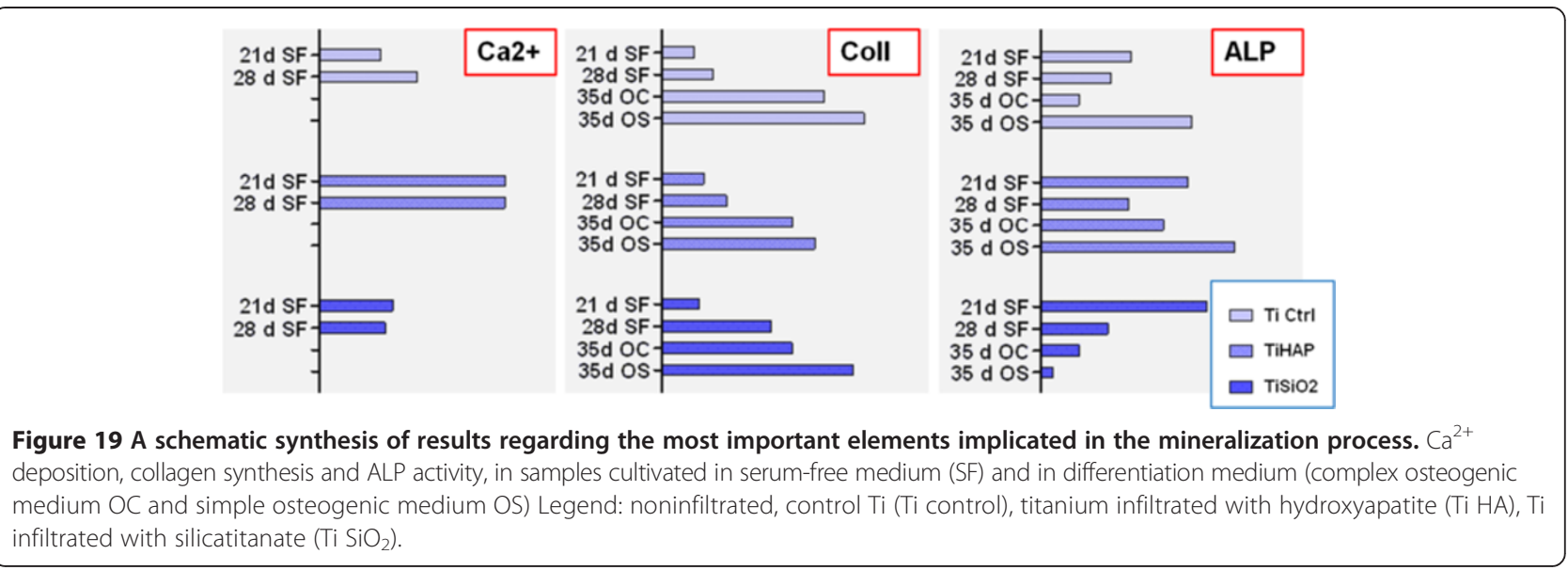

because in such implants the collagen fibers could not be visualized (as they may have been masked by the accelerated deposition of newly formed HA crystals).

Calcium deposition was investigated as a marker of mineralization. Differences between implants emerged after 21 and 28 days of cultivation in complete medium, with a gradual increase in calcium deposition observed mostly in Ti HA implants and in a lower degree in $\mathrm{Ti}$ $\mathrm{SiO}_{2}$ implants. Serum-free medium significantly increased the deposition of calcium on the surface of $\mathrm{Ti}$ HA implants after 28 days of cultivation. A similar outcome was reported by Yamada et al. [61], as they observed accelerated bone-implant integration after the addition of pure nanopolymorphic crystalline HA to micro-roughened titanium, as well as a significantly increased osteoconductivity [61].

The complex osteogenic differentiation medium used in this study also contained TGF- $\beta 1$ (in a low dose- $3 \mathrm{ng} /$ $\mathrm{ml}$ ), a growth factor with dual biological activity, as it can regulate osteoblast differentiation not only positively but also negatively. Ochiai et al. [62] observed that only repeated high doses of TGF- $\beta 1$ suppressed osteoblast differentiation with decreased ALP activity, although a unique low dose of TGF- $\beta 1$ strongly induced osteoblast differentiation [62]. On the other hand, TGF- $\beta 1$ protects pre-osteocytes from apoptosis [63]. Similar results regarding the osteogenic medium were obtained by Tirkkonen et al. [64] in an adipose stem cell osteogenic differentiation study that compared the efficiency of BMP-2 and BMP-7, VEGF and osteogenic medium. Stem cells were grown on commercially available bioactive glass scaffolds and biphasic granules. The bioactive glass induced an increased cell proliferation whereas calcium phosphate led to a more significant collagen production. They did not find a benefit after the addition ofgrowth factors in comparison with plain osteogenic medium. Moreover, BMP-7 inhibited the proliferation and osteogenic differentiation of adipose stem cells [64]. The lack of improvement of the osteogenic differentiation of stem cells through the addition of BMP2 or BMP-6 was also reported by other authors [65-67]. The master of controlling osteoblast differentiation into osteocytes is RUNX2 (runt-related transcription factor) [68] and in this context BMP2 induces osteoblast differentiation through Runx2-dependent ATF6 (bZIP transcription factor) expression, which directly regulates osteocalcin transcription [69]. Prior to the mineralization process, as the cells pass through progressive differentiation stages, some specific markers are revealed, the earliest being RUNX2, followed by ALP (an early-mid marker), osteopontin (OP), osteocalcin (OC) and osteonectin (ON) [70]. Roach (1996) studied the roles of matrix noncollagenous proteins such as OP, OC, bone sialo-protein (BSP) and ON and their tissue localization using double immuno-histochemistry. The appearance of OP and BSP ahead of the mineralization front, prior to mineralization, suggested that both proteins are necessary for the initiation of bone mineralization. $\mathrm{OC}$ and $\mathrm{ON}$ were present in fully mineralized matrix, possibly having a function in controlling the amount and rate of crystals formation [71].

In our study, after the immunocytochemical analysis, osteocalcin had the highest expression in $\mathrm{Ti}_{\mathrm{SiO}_{2}}$ and Ctrl Ti implants after 28 days of cultivation, and it was associated with increased expression of collagen I. Such effects of bioactive glass were explained by Silver et al. [72], through a marked alkalinization of the intracellular and extracellular environment that influence the activities of intracellular enzymes and signaling pathways, which in turn increases collagen synthesis [72]. Similar observations were reported regarding orthosilicic acid or different types of bioglasses [73,74]. Osteocalcin, a terminal marker of osteoblastic differentiation, is present in high amounts in the bone matrix. It binds calcium and inhibits bone growth by inhibiting the activity of transglutaminase [75]. After posttranslational modification with the addition of carboxylated glutamic acid residues (gla residues), OC gains a high affinity for hydroxyapatite 
crystals. The inhibitory role of $\mathrm{OC}$ possibly involves a conservation of cells in a late-osteoblast stage of differentiation, with associated prevention of osteocytic differentiation [76] and initiation of the remodeling process of new bone.

Through interpretation of the results derived from our study, two kinds of osseointegrations were found. The first type consists of a predominant collagen protein matrix construct and a self-limiting mineralization process through increased expression of osteocalcin, which was observed in the case of the porous titanium and infiltrated silicatitanate implants. The second type belongs to HAinfiltrated titanium, characterized by an early increase in calcium deposits, with a lesser degree of collagen and non-collagenous protein synthesis. Both types of osseointegration have potential applications, however in vivo studies are required to clarify the most suitable type of implant depending on the site of implantation (considering the mechanical load and the type of bone in need of repair) as well as the associated pathological conditions such as osteoporosis. Despite some limitations regarding the mechanical properties of porous apatite ceramics, the excellent osteoconductivity of HA coatings and the possibility of associating bioactive molecules (such as proteins, aminoacids, antibiotics, growth factors, anticancer and anti-osteoporosis drugs) to calcium phosphate indicate the potential advantages of the use of this type of coating especially in osteopenic bone repair $[77,78]$. On the other hand, the osseoinductive properties of $\mathrm{SiO}_{2}$-coated $\mathrm{Ti}$ implants (as described in our study) and their ability to promote angiogenesis and enhance neocartilage formation [73], can provide other important applications in implantology, especially for repairing bones at sites where mechanical strength is of lesser importance.

\section{Conclusions}

Two types of titanium coatings were comparatively studied with regard to bone regeneration, and they induced different behaviors of osteoblastic cells. Ti implants infiltrated with hydroxyapatite (HA) demonstrated an increased capacity to induce early mineralization with a lower ability to induce cell adhesion and proliferation. Conversely, the implants infiltrated with $\mathrm{SiO}_{2}$, as well as porous titanium preserved the attachment and adhesion of osteoblasts, promoted celldifferentiation and induced the production of the protein component of the extracellular matrix (collagen and the non-collagenic proteins osteopontin and osteocalcin). The addition of growth factors BMP- 2 and TGF $\beta 1$ in the differentiation medium did not improve the mineralization process. Both types of coatings have their advantages and limitations, which can be exploited depending on the local conditions and on the bone lesions in need of repair. Their properties can be improved through methods of functionalization with biomolecules involved in osteogenesis.

\section{Competing interests}

The authors declare that they have no competing interests.

\section{Authors' contributions}

Study design: PB, SS, CP, IB, OS, VC Scaffolds manufacturing: CP, MT, SS, CB Scanning electron microscopy and EDX analysis: AV Cell cultures: MPS, ND, OB Biocompatibility assays: OS, GC, PV, CB Data analysis: IB, OS, TM, AV, CP, MT Data interpretation. IB, OS, Manuscript preparation: IB, OS, MPS, MT, AV. Approving final version of manuscript: IB and OS takes responsibility for the integrity of the data analysis. All authors read and approved the final manuscript.

\section{Acknowledgements}

This study was supported within the PCCE contract 5/2010, BIOMAPIM project and PN-II-PT-PCCA-2011-3, contract no. 78/2012, financed by the Romanian National Council for the Higher Education Scientific Research. ND would like to thank to Technical University, Cluj-Napoca PhD program (contract 19585/2012) for financial support.

\section{Author details}

"The Institute of Oncology "Prof. Dr. I. Chiricuta" Cluj-Napoca, Cluj-Napoca, Romania. "University of Medicine and Pharmacy "Iuliu Hatieganu"

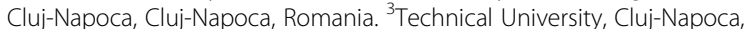
Romania. ${ }^{4}$ Faculty of Physics \& Institute of Interdisciplinary Research in Bio-Nano-Sciences, Babes Bolyai University, 400084 Cluj-Napoca, Romania.

Received: 6 December 2013 Accepted: 13 June 2014

Published: 19 June 2014

\section{References}

1. Baroli B: From natural bone grafts to tissue engineering therapeutics: brainstorming on pharmaceutical formulative requirements and challenges. J Pharm Sci 2009, 98(4):1317-1375.

2. Amini AR, Laurencin CT, Nukavarapu SP: Bone Tissue Engineering: Recent Advances and Challenges. Crit Rev Biomed Eng 2012, 40(5):363-408.

3. Sul $Y T$, Johansson CB, Petronis $S$, Krozer A, Jeong $Y$, Wennerberg A, Albrektsson T: Characteristics of the surface oxides on turned and electrochemically oxidized pure titanium implants up to dielectric breakdown: the oxide thickness, micropore configurations, surface roughness, crystal structure and chemical composition. Biomaterials 2002, 23:491-501.

4. Park H, Temenoff JS, Mikos AG: Biodegradable orthopedic implants. In Engineering of functional skeletal tissues. Edited by Bronner F, Farch-Carson MC, Mikos AG. London: Spriinger-Verlagm; 2007:60.

5. Ventre M, Causa F, Netti PA: Determinants of cell-material crosstalk at the interface: towards engineering of cell instructive materials. J R Soc Interface 2012, 9:2017-2032.

6. Nautiyal VP, Mittal A, Agarwal A, Pandey A: Tissue response to titanium implant using scanning electron microscope. Natl J Maxillofac Surg 2013, 4(1):7-12.

7. Ungersboeck $A$, Geret $V$, Pohler $\mathrm{O}$, Schuetz $\mathrm{M}$, Wuest W: Tissue reaction to bone plates made of pure titanium: a prospective, quantitative clinical study. J Mater Sci Mater Med 1995, 6:223-229.

8. Vijayaraghavan $V$, Sabane AV, Tejas K: Hypersensitivity to titanium: a less explored area of research. J Indian Prosthodont Soc 2012, 12(4):201-207.

9. Donesz-Sikorska A, Krzak-Roś J, Kochanowska IE, Będziński R, Kaleta J: New specific metal-silica biocomposites for medical implants. Bioinspired, Biomimetic and Nanobiomaterials 08/2012; doi:10.1680/bbn.12.00018.

10. Nouri A, Hodgson PD, Wen C: Chapter 21- Biomimetic Porous Titanium Scaffolds for Orthopaedic and Dental Applications. In Biomimetics, Learning from nature. Edited by Amitava M, In-Tech. 2009:415-450.

11. Marcu T, Todea M, Maines L, Leordean D, Berce P, Popa C: Metallurgical and mechanical characterisation of titanium based materials for endosseous applications obtained by selective laser melting. Powder Metall 2012, 55(4):309-314.

12. Kim HM: Ceramic bioactivity and related biomimetic strategy. Curr Opinion Solid State Mater Sci 2003, 7:289-299. 
13. Jones JR: Review of bioactive glass: from Hench to hybrids. Acta Biomater 2013, 9(1):4457-4486

14. Polo-Corrales L, Latorre-Esteves M, Ramirez-Vick JE: Scaffold design for bone regeneration. J Nanosci Nanotechnol 2014, 14(1):15-56.

15. Ning $C Q$, Zhou $Y$ : On the microstructure of biocomposites sintered from Ti, HA and bioactive glass. Biomaterials 2004, 25:3379-3387.

16. Wu Z, He L, Chen Z: Fabrication and characterization of hydroxyapatite/ Al2O3 biocomposite coating on titanium. Trans Nonferrous Met Soc China 2006, 16:259-266.

17. Wang CK, Lin JH, Ju CP, Ong HC, Chang RP: Structural characterization of pulsed laser-deposited hydroxyapatite film on titanium substrate. Biomaterials 1997, 18(20):1331-1338.

18. Prosecká E, Buzgo M, Rampichová M, Kocourek T, Kochová P, Vysloužilová L, Trrdík D, Jelínek M, Lukáš D, Amler E: Thin-layer hydroxyapatite deposition on a nanofiber surface stimulates mesenchymal stem cell proliferation and their differentiation into osteoblasts. J Biomed Biotechnol 2012, 428503:10. doi:10.1155/2012/428503.

19. Roy M, Balla VK, Bandyopadhyay A, Bose S: Compositionally graded hydroxyapatite/ tricalcium phosphate coating on Ti by laser and induction plasma. Acta Biomater 2011, 7(2):866-873. doi:10.1016/j.actbio.2010.09.016.

20. Hannora AE, Mukasyan AS, Mansurov ZA: Nanocrystalline hydroxyapatite/s coating by mechanical alloying technique. Bioinorg Chem Appl 2012, 390104:14. doi:10.1155/2012/390104.

21. Kim HW, Kim HE, Knowles JC: Fluor-hydroxyapatite sol-gel coating on titanium substrate for hard tissue implants. Biomaterials 2004 25(17):3351-3358.

22. Lin FH, Hsu YS, Lin SH, Sun JS: The effect of $\mathrm{Ca} / \mathrm{P}$ concentration and temperature of simulated body fluid on the growth of hydroxyapatite coating on alkali-treated 316 L stainless steel. Biomaterials 2002, 23(19):4029-4038.

23. Eraković S, Janković A, Veljović D, Palcevskis E, Mitrić M, Stevanović T, Janaćković D, Mišković-Stanković V: Corrosion stability and bioactivity in simulated body fluid of silver/ hydroxyapatite and silver/ hydroxyapatite/ lignin coatings on titanium obtained by electrophoretic deposition. J Phys Chem B 2013, 117(6):1633-1643. doi:10.1021/jp305252a.

24. Mozafari M, Salahinejad E, Shabafrooz V, Yazdimamaghani M, Vashaee D, Tayebi L: Multilayer bioactive glass/zirconium titanate thin films in bone tissue engineering and regenerative dentistry. Int J Nanomedicine 2013, 8:1665-1672.

25. Saino E, Maliardi V, Quartarone E, Fassina L, Benedetti L, De Angelis MG, Mustarelli P, Facchini A, Visai L: In vitro enhancement of SAOS-2 cell calcified matrix deposition onto radio frequency magnetron sputtered bioglass-coated titanium scaffolds. Tissue Eng Part A 2010, 16(3):995-1008,

26. Leordean D, Dudescu C, Marcu T, Berce P, Bâlc N: Aspects related to the application of the selective laser melting technology to customized Ti-6Al-7Nb implants. J Rapid Prototyping, in press.

27. Tomuleasa Cl, Foris V, Soritau O, Pall E, Fisher-Fodor E, Lung-llles V, Brie I, Virag P, Perde-Schrepler M, Postescu ID, Chereches G, Barbos O, Tatomir C: Effects of ${ }^{60} \mathrm{Co} \gamma$-rays on human osteoprogenitor cells. Rom J Morphol Embryol 2009, 50(3):349-355.

28. Søballe K: Hydroxyapatite ceramic coating for bone implant fixation. Mechanical and histological studies in dogs. Acta Orthop Scand Suppl 1993, 255:1-58.

29. Yim EK, Leong KW: Significance of synthetic nanostructures in dictating cellular response. Nanomedicine 2005, 1(1):10-21.

30. Wang G, Lu Z, Liu X, Zhou X, Ding C, Zreiqat H: Nanostructured glass-ceramic coatings for orthopaedic applications. J R Soc Interface 2011, 8(61):1192-1203. doi:10.1098/rsif.2010.0680

31. Ponche A, Bigerelle M, Anselme K: Relative influence of surface topography and surface chemistry on cell response to bone implant materials. Part 1: Physico-chemical effects. Proc Inst Mech Eng H J Eng Med 2010, 224:1471.

32. Kitsugi T, Yamamuro T, Nakamura T, Oka M: Transmission electron microscopy observations at the interface of bone and four types of calcium phosphate ceramics with different calcium/phosphorus molar ratios. Biomaterials 1995, 16(14):1101-1107.

33. Chou YF, Huang W, Dunn JC, Miller TA, Wu BM: The effect of biomimetic apatite structure on osteoblast viability, proliferation, and gene expression. Biomaterials 2005, 26(3):285-295.

34. Goto T, Yoshinari M, Kobayashi S, Tanaka T: The initial attachment and subsequent behavior of osteoblastic cells and oral epithelial cells on titanium. Biomed Mater Eng 2004, 14(4):537-544.
35. Rampersad SN: Multiple applications of Alamar Blue as an indicator of metabolic function and cellular health in cell viability bioassays. Sensors (Basel) 2012, 12(9):12347-12360. doi:10.3390/s120912347.

36. Geys J, Nemery B, Hoet PH: Assay conditions can influence the outcome of cytotoxicity tests of nanomaterials: better assay characterization is needed to compare studies. Toxicol In Vitro 2010, 24(2):620-629. doi:10.1016/j.tiv.2009.10.007.

37. Zeller KS, Riaz A, Sarve H, Li J, Tengholm A, Johansson S: The role of mechanical force and ROS in integrin-dependent signals. PLOS ONE, 8(5):e64897. doi:10.1371/journal.pone.0064897.

38. Harmey D, Hessle L, Narisawa S, Johnson KA, Terkeltaub R, Millán JL: Concerted regulation of inorganic pyrophosphate and osteopontin by akp2, enpp1, and ank: an integrated model of the pathogenesis of mineralization disorders. Am J Pathol 2004, 164(4):1199-1209.

39. Addison WN, Azari F, Sørensen ES, Kaartinen MT, McKee MD: Pyrophosphate inhibits mineralization of osteoblast cultures by binding to mineral, up-regulating osteopontin, and inhibiting alkaline phosphatase activity. J Biol Chem 2007, 282(21):15872-15883.

40. Khan MR, Donos N, Salih V, Brett PM: The enhanced modulation of key bone matrix components by modified Titanium implant surfaces. Bone 2012, 50(1):1-8. doi:10.1016/j.bone.2011.07.040.

41. Albrektsson T, Johansson C: Osteoinduction, osteoconduction and osseointegration. Eur Spine J 2001, 10(Suppl 2):S96-S101.

42. Barradas AM, Yuan $H$, Van Blitterswijk CA, Habibovic P: Osteoinductive biomaterials: current knowledge of properties, experimental models and biological mechanisms. Eur Cell Mater 2011, 21:407-429.

43. Anselme K, Ponche A, Bigerelle M: Relative influence of surface topography and surface chemistry on cell response to bone implant materials. Part 2: biological aspects. Proc Inst Mech Eng H 2010, 224(12):1487-1507

44. Lutolf MP, Hubbell JA: Synthetic biomaterials as instructive extracellular microenvironments for morphogenesis in tissue engineering. Nat Biotechnol 2005, 23:47-55.

45. Waselau M, Patrikoski M, Juntunen M, Kujala K, Kääriäinen M, Kuokkanen $H_{1}$ Sándor GK, Vapaavuori O, Suuronen R, Mannerström B, Von Rechenberg B, Miettinen S: Effects of bioactive glass S53P4 or beta-tricalcium phosphate and bone morphogenetic protein- 2 and bone morphogenetic protein- 7 on osteogenic differentiation of human adipose stem cells. J Tissue Eng 2012, 3(1):2041731412467789. doi:10.1177/2041731412467789.

46. Drnovšek N, Novak S, Dragin U, Čeh M, Gorenšek M, Gradišar M: Bioactive glass enhances bone ingrowth into the porous titanium coating on orthopaedic implants. Int Orthop 2012, 36(8):1739-1745. doi:10.1007/ s00264-012-1520-y.

47. Ponta O, Vanea E, Cheniti A, Berce P, Simon S: Structural and surface characterization of nanostructured spray dried titanosilicate microspheres. Mater Chem Phys 2012, 135:863-869.

48. Rahaman MN, Day DE, Bal BS, Fu Q, Jung SB, Bonewald LF, Tomsia AP: Bioactive glass in tissue engineering. Acta Biomater 2011, 7(6):2355-2373. doi:10.1016/j.actbio.2011.03.016

49. Mahony O, Jones JR: Porous bioactive nanostructured scaffolds for bone regeneration: a sol-gel solution. Nanomedicine (Lond) 2008, 3(2):233-245. doi:10.2217/17435889.3.2.233.

50. Pamula E, Kokoszka J, Cholewa-Kowalska K, Laczka M, Kantor L, Niedzwiedzki L, Reilly GC, Filipowska J, Madej W, Kolodziejczyk M, Tylko G, Osyczka AM: Degradation, bioactivity, and osteogenic potential of composites made of PLGA and two different sol-gel bioactive glasses. Ann Biomed Eng 2011, 39(8):2114-2129. doi:10.1007/s10439-011-0307-4.

51. Jones JR, Lin S, Yue S, Lee PD, Hanna JV, Smith ME, Newport RJ: Bioactive glass scaffolds for bone regeneration and their hierarchical characterisation. Proc Inst Mech Eng H 2010, 224(12):1373-1387.

52. Jugdaohsingh R: Silicon and bone health. J Nutr Health Aging 2007, 11(2):99-110.

53. McKee MD, Nanci A: Osteopontin at mineralized tissue interfaces in bone, teeth, and osseointegrated implants: ultrastructural distribution and implications for mineralized tissue formation, turnover, and repair. Microsc Res Tech 1996, 33(2):141-164.

54. Gericke A, Qin C, Spevak L, Fujimoto Y, Butler WT, Sørensen ES, Boskey AL: Importance of phosphorylation for osteopontin regulation of biomineralization. Calcif Tissue Int 2005, 77(1):45-54.

55. Vandrovcová M, Bačáková L: Adhesion, growth and differentiation of osteoblasts on surface-modified materials developed for bone implants. Physiol Res 2011, 60(3):403-417. 
56. Roffers-Agarwal J, Xanthos JB, Miller JR: Regulation of actin cytoskeleton architecture by Eps8 and Abi1. BMC Cell Biol 2005, 6:36.

57. Orza A, Soritau O, Olenic L, Diudea M, Florea A, Rus Ciuca D, Mihu C, Casciano D, Biris AS: Electrically conductive gold-coated collagen nanofibers for placental-derived mesenchymal stem cells enhanced differentiation and proliferation. ACS Nano 2011, 5(6):4490-4503. doi:10.1021/nn1035312.

58. Galli C, Piemontese M, Lumetti S, Ravanetti F, Macaluso GM, Passeri G: Actin cytoskeleton controls activation of Wnt/ $\beta$-catenin signaling in mesenchymal cells on implant surfaces with different topographies. Acta Biomater 2012, 8(8):2963-2968. doi:10.1016/j.actbio.2012.04.043.

59. Kazanecki CC, Uzwiak DJ, Denhardt DT: Control of osteopontin signaling and function by post-translational phosphorylation and protein folding. J Cell Biochem 2007, 102(4):912-924.

60. Hunter LW, Shiekh FA, Pisimisis GT, Kim SH, Edeh SN, Miller VM, Lieske JC: Key role of alkaline phosphatase in the development of human-derived nanoparticles in vitro. Acta Biomater 2011, 7(3):1339-1345. doi:10.1016/j. actbio.2010.10.027

61. Yamada M, Ueno T, Tsukimura N, Ikeda T, Nakagawa K, Hori N, Suzuki T, Ogawa T: Bone integration capability of nanopolymorphic crystalline hydroxyapatite coated on titanium implants. Int J Nanomedicine 2012, 7:859-873. doi:10.2147/IJN.S28082

62. Ochiai H, Okada S, Saito A, Hoshi K, Yamashita H, Takato T, Azuma T: Inhibition of insulin-like growth factor-1 (IGF-1) expression by prolonged transforming growth factor- $\beta 1$ (TGF- $\beta 1$ ) administration suppresses osteoblast differentiation. J Biol Chem 2012, 287(27):22654-22661. doi:10.1074/jbc.M111.279091.

63. Kanaan RA, Kanaan LA: Transforming growth factor beta1, bone connection. Med Sci Monit 2006, 12(8):RA164-RA169.

64. Tirkkonen L, Haimi S, Huttunen S, Wolff J, Pirhonen E, Sándor GK, Miettinen S: Osteogenic medium is superior to growth factors in differentiation of human adipose stem cells towards bone-forming cells in 3D culture. Eur Cell Mater 2013, 25:144-158.

65. Cruz AC, Silva ML, Caon T, Simões CM: Addition of bone morphogenetic protein type 2 to ascorbate and $\beta$-glycerophosphate supplementation did not enhance osteogenic differentiation of human adipose-derived stem cells. J Appl Oral Sci 2012, 20(6):628-635.

66. Zuk P, Chou YF, Mussano F, Benhaim P, Wu BM: Adipose-derived stem cells and BMP2: part 2. BMP2 may not influence the osteogenic fate of human adipose-derived stem cells. Connect Tissue Res 2011, 52(2):119-132. doi:10.3109/03008207.2010.484515.

67. Khanna-Jain R, Agata H, Vuorinen A, Sándor GK, Suuronen R, Miettinen S: Addition of BMP-2 or BMP-6 to dexamethasone, ascorbic acid, and $\beta$-glycerophosphate may not enhance osteogenic differentiation of human periodontal ligament cells. Growth Factors 2010, 28(6):437-446. doi:10.3109/08977194.2010.495719.

68. Raggatt LJ, Partridge NC: Cellular and Molecular Mechanisms of Bone Remodeling. J Bio/ Chem 2010, 285(33):25103-25108. doi:10.1074/jbc. R109.041087.

69. Jang WG, Kim EJ, Kim DK, Ryoo HM, Lee KB, Kim SH, Choi HS, Koh JT: BMP2 protein regulates osteocalcin expression via Runx2-mediated Atf6 gene transcription. J Biol Chem 2012, 287(2):905-915. doi:10.1074/jbc.M111.253187.

70. Pilia M, Guda T, Shiels SM, Appleford MR: Influence of substrate curvature on osteoblast orientation and extracellular matrix deposition. J Biol Eng 2013, 7(1):23.

71. Roach HI: Why does bone matrix contain non-collagenous proteins? The possible roles of osteocalcin, osteonectin, osteopontin and bone sialoprotein in bone mineralisation and resorption. Cell Biol Int 1994 18(6):617-628.

72. Silver IA, Deas J, Erecińska M: Interactions of bioactive glasses with osteoblasts in vitro: effects of 45S5 Bioglass, and $58 \mathrm{~S}$ and $77 \mathrm{~S}$ bioactive glasses on metabolism, intracellular ion concentrations and cell viability. Biomaterials 2001, 22(2):175-185.

73. Arumugam MQ, Ireland DC, Brooks RA, Rushton N, Bonfield W: The Effect Orthosilicic Acid on Collagen Type I, Alkaline Phosphatase and Osteocalcin mRNA Expression in Human Bone-Derived Osteoblasts. In Vitro Key Engineering Materials 2006, 309-311:125. doi:10.4028/www. scientific.net/KEM.254-256.869.

74. Bosetti M, Zanardi L, Hench L, Cannas M: Type I collagen production by osteoblast-like cells cultured in contact with different bioactive glasses. J Biomed Mater Res A 2003, 64(1):189-195.
75. Meury T, Akhouayri O, Jafarov T, Mandic V, St-Arnaud R: Nuclear alpha NAC influences bone matrix mineralization and osteoblast maturation in vivo. Mol Cell Biol 2010, 30(1):43-53. doi:10.1128/MCB.00378-09.

76. Boskey AL, Gadaleta S, Gundberg C, Doty SB, Ducy P, Karsenty G: Fourier transform infrared microspectroscopic analysis of bones of osteocalcin-deficient mice provides insight into the function of osteocalcin. Bone 1998, 23:187-196.

77. Gómez-Morales J, lafisco M, Delgado-López JM, Sarda S, Drouet C: Progress on the preparation of nanocrystalline apatites and surface characterization: Overview of fundamental and applied aspects. Prog Cryst Growth Charact Mater 2013, 59:1-46.

78. Hayashi K, Fotovati A, Ali SA, Oda K, Oida H, Naito M: Prostaglandin EP4 receptor agonist augments fixation of hydroxyapatite-coated implants in a rat model of osteoporosis. J Bone Joint Surg (Br) 2005, 87(8):1150-1156.

doi:10.1186/1754-1611-8-14

Cite this article as: Brie et al:: Comparative in vitro study regarding the biocompatibility of titanium-base composites infiltrated with hydroxyapatite or silicatitanate. Journal of Biological Engineering 2014 8:14.

\section{Submit your next manuscript to BioMed Central and take full advantage of:}

- Convenient online submission

- Thorough peer review

- No space constraints or color figure charges

- Immediate publication on acceptance

- Inclusion in PubMed, CAS, Scopus and Google Scholar

- Research which is freely available for redistribution 